\title{
Interrogating COVID-19 Vaccine Hesitancy in the Philippines with a Nationwide Open-Access Online Survey
}

\begin{abstract}
Alexandria Caple ${ }^{1}$, Arnie O. Dimaano ${ }^{2+}$, Marc Martin C. Sagolili ${ }^{2+}$, April Anne M. $\mathrm{Uy}^{2+}$, Panjee Mariel G. Aguirre ${ }^{3}$, Dean Lotus C. Alano ${ }^{2}$, Giselle Sophia M. Camaya ${ }^{2}$, Brent John A. Ciriaco ${ }^{3}$, Princess Jerah S. Clavo ${ }^{2}$, Dominic G. Cuyugan², Cleinne Florence Geeseler V. Fermo², Paul Jeremy C. Lanete ${ }^{2}$, Ardwayne Jurel D. La Torre ${ }^{3}$, Thomas Albert T. Loteyro ${ }^{3}$, Raisa Mikaela Lua ${ }^{2}$, Nicole Gayle R. Manansala², Raphael Willard M. Mosquito², Alexa Marie C. Octaviano², Alexandra Erika T. Orfanel ${ }^{2}$, Gheyanna Merly U. Pascual ${ }^{2}$, Aubrey Joy S. Sale ${ }^{2}$, Sophia Lorraine S. Tendenilla ${ }^{2}$, Maria Sofia Lauren R. Trinidad ${ }^{2}$, Nicole Jan S. Trinidad ${ }^{2}$, Daphne Louise V. Verano $^{2}$, and Nicanor Austriaco ${ }^{2,4, *}$
\end{abstract}

${ }^{1}$ Department of Psychology, Providence College, 1 Cunningham Square, Providence, Rhode Island 02918, U.S.A., ${ }^{2}$ Department of Biological Sciences, University of Santo Tomas, España Blvd., Manila 1015, Philippines,

${ }^{3}$ Department of Advertising Arts, University of Santo Tomas, España Blvd., Manila 1015, Philippines, ${ }^{4}$ Department of Biology, Providence College, 1 Cunningham Square, Providence, Rhode Island 02918, U.S.A.

${ }^{+}$These authors contributed equally to the work.

*Corresponding author: Rev. Fr. Nicanor Austriaco, O.P. (naustriaco@ust.edu.ph) 
medRxiv preprint doi: https://doi.org/10.1101/2021.09.11.21263428; this version posted September 15, 2021. The copyright holder for this preprint (which was not certified by peer review) is the author/funder, who has granted medRxiv a license to display the preprint in perpetuity.

It is made available under a CC-BY-NC-ND 4.0 International license .

\begin{abstract}
To mitigate the unprecedented health, social, and economic damage of COVID-19,
\end{abstract} the Philippines is undertaking a nationwide vaccination program to mitigate the effects of the global pandemic. In this study, we interrogated COVID-19 vaccine hesitancy in the country by deploying a nationwide open-access online survey, two months before the rollout of the national vaccination program. The Health Belief Model (HBM) posits that people are likely to adopt disease prevention behaviors and to accept medical interventions like vaccines if there is sufficient motivation and cues to action. A majority of our 7,193 respondents $(62.5 \%)$ indicated that they were willing to be vaccinated against COVID19. Moreover, multivariable analysis revealed that HBM constructs were associated with vaccination intention in the Philippines. Perceptions of high susceptibility, high severity, and significant benefits were all good predictors for vaccination intent. We also found that external cues to action were important. Large majorities of our respondents would only receive the COVID-19 vaccines after many others had received it (72.8\%) or after politicians had received it $(68.2 \%)$. Finally, our study revealed that most $(21 \%)$ were willing to pay an amount of PHP1,000 [USD20] for the COVID-19 vaccines with an average willing-to-pay amount of PHP1,892 [USD38]. 
medRxiv preprint doi: https://doi.org/10.1101/2021.09.11.21263428; this version posted September 15, 2021. The copyright holder for this preprint (which was not certified by peer review) is the author/funder, who has granted medRxiv a license to display the preprint in perpetuity.

It is made available under a CC-BY-NC-ND 4.0 International license.

\section{INTRODUCTION}

On January 30, 2020, the Department of Health (DOH) of the Philippines reported its first case of COVID-19, a novel respiratory disease first identified in Wuhan, China, that is caused by the coronavirus, SARS-CoV-2 (Xie et al., 2020; Zhu et al., 2020; Guan et al., 2020). With widespread human-to-human transmission, the virus is highly contagious, and the COVID-19 pandemic is now of global concern (Burki, 2020; Paules, Marston \& Fauci, 2020; Case et al., 2021; Novelli et al., 2021). As of August 25, 2021, there have been 1,883,088 confirmed cases and 32,492 deaths from COVID-19 reported by the DOH throughout the archipelago (ncovtracker.doh.gov.ph).

Vaccination has long been regarded as the most effective means for combating infectious disease (Rappuoli et al., 2014; Sathyanarayana et al., 2020). The Philippines began its national vaccine drive against COVID-19 on March 1, 2021, with the goal of vaccinating seventy million of its citizens by the end of the calendar year (Inter-Agency Task Force for the Management of Emerging Infectious Disease, 2021). One of the ongoing challenges for this campaign is the vaccine hesitancy among the Filipino people (Alfonso et al., 2021).

The Health Belief Model (HBM) posits that people are likely to adopt disease prevention behaviors and to accept medical interventions like vaccines if there is sufficient motivation and cues to action (Rosenstock, Strecher \& Becker, 1988). Motivational factors 
medRxiv preprint doi: https://doi.org/10.1101/2021.09.11.21263428; this version posted September 15, 2021. The copyright holder for this preprint (which was not certified by peer review) is the author/funder, who has granted medRxiv a license to display the preprint in perpetuity.

It is made available under a CC-BY-NC-ND 4.0 International license .

include perceived susceptibility to and severity of the disease and perceived benefits of the vaccine. Cues to action include information, people, and events that nudge the individual towards vaccination. The HBM has been adopted as a conceptual framework that has been used to evaluate the beliefs and attitudes toward a diversity of vaccines including the influenza, human papillomavirus, and hepatitis B vaccines (Teitler-Regev, Shahrabani \& Benzion, 2011; Donadiki et al., 2014; Hu et al., 2017; Chen et al., 2019). Moreover, several studies have shown that the HBM constructs can serve as an important predictor of influenza vaccination uptake (Brewer et al., 2007; Shahrabani, Benzion \& Yom Din, 2009; Shahrabani \& Benzion, 2010; Tsutsui, Benzion \& Shahrabani, 2012). During the COVID-19 pandemic, the HBM was used to assess the root causes of COVID-19 vaccine hesitancy in the Asia-Pacific region and beyond (Wong et al., 2020, 2021; Lin et al., 2020; Yu et al., 2021; Kabir et al., 2021; Shmueli, 2021; Huynh et al., 2021; Tao, Wang \& Liu, 2021; Mahmud et al., 2021; Banik et al., 2021).

In this study, we interrogated COVID-19 vaccine hesitancy in the Philippines by deploying a nationwide open-access online survey, two months before the rollout of the national vaccination program. Based on the HBM framework, we hypothesized that acceptance of a COVID-19 vaccine depends upon beliefs about susceptibility to and severity of COVID-19, and beliefs about the perceived benefits of the vaccine. We also wanted to assess possible cues to vaccination for our Filipino respondents. 
medRxiv preprint doi: https://doi.org/10.1101/2021.09.11.21263428; this version posted September 15, 2021. The copyright holder for this preprint (which was not certified by peer review) is the author/funder, who has granted medRxiv a license to display the preprint in perpetuity.

It is made available under a CC-BY-NC-ND 4.0 International license.

A majority of our 7,193 respondents (62.5\%) indicated that they were willing to be vaccinated against COVID-19. Moreover, multivariable analysis revealed that HBM constructs were associated with vaccination intention in the Philippines. Perceptions of high susceptibility, high severity, and significant benefits were all good predictors for vaccination intent. We also found that external cues to action were important. Large majorities of our respondents would only receive the COVID-19 vaccines after many others had received it $(72.8 \%)$ or after politicians had received it $(68.2 \%)$. Finally, our study revealed that most $(21 \%)$ were willing to pay an amount of PHP1,000 [USD20] for the COVID-19 vaccines with an average willing-to-pay amount of PHP1,892 [USD38]. Based on these findings, we inaugurated the UST-CoVAX public awareness campaign that seeks to increase vaccine confidence in the Philippines by addressing the specific fears and concerns of our Filipino respondents and by sharing the personal vaccination testimonies of Filipinos around the world.

\section{METHODS}

\section{Participants and Survey Design}

The current study design was a cross-sectional, anonymous, web-based surveydeveloped using Qualtrics — conducted from January 15, 2021 to January 29, 2021. Our research team deployed an anonymous link via the social platforms of the University of 
medRxiv preprint doi: https://doi.org/10.1101/2021.09.11.21263428; this version posted September 15, 2021. The copyright holder for this preprint (which was not certified by peer review) is the author/funder, who has granted medRxiv a license to display the preprint in perpetuity.

It is made available under a CC-BY-NC-ND 4.0 International license .

Santo Tomas (UST) like Twitter and Facebook and university mailing lists including the

UST School of Science and UST Student Council to distribute the survey. Participants were encouraged to distribute the survey link to their contacts throughout the country.

The questionnaire was written in both Filipino and English. Responses used for data collection were limited to respondents who were at least 18 years old.

\section{Survey Instrument}

The survey consisted of questions and statements that assessed the following: 1) demographics, health status, and COVID-19 experience, 2) intent to receive a COVID-19 vaccine; 3) perceived susceptibility to and severity of COVID-19; 4) perceived benefits of a COVID-19 vaccine; 5) willingness to pay (WTP) for a COVID-19 vaccine; and 6) confidence in COVID-19 vaccines made in other countries.

Demographics, health status, and COVID-19 experience: Demographic information including age, gender, marital status, education, occupation, monthly income, and urban or rural location of residence were collected. Participants were also asked if they have an existing chronic condition, if they ever tested positive for COVID-19, and to indicate if they know someone who has tested positive for COVID-19.

Intent to receive a COVID-19 vaccine: Intention to receive a COVID-19 vaccine was assessed using a one-item question ("If a vaccine for COVID-19 is available in the 
medRxiv preprint doi: https://doi.org/10.1101/2021.09.11.21263428; this version posted September 15, 2021. The copyright holder for this preprint (which was not certified by peer review) is the author/funder, who has granted medRxiv a license to display the preprint in perpetuity.

It is made available under a CC-BY-NC-ND 4.0 International license .

Philippines, would you use it?") on a five-point scale ranging from $1=$ 'definitely no' to $5=$ 'definitely yes'. Responses were additionally recoded into two distinct categories: vaccine hesitant (responses included: 'definitely no', 'probably no', and 'unsure') and not vaccine hesitant (responses included: 'probably yes' and 'definitely yes').

Perceived susceptibility to and severity of COVID-19: HBM-derived items were used to assess individual beliefs about a COVID-19 vaccine. Questions posed to participants assessed perceived susceptibility of COVID-19 (two items), perceived severity of COVID-19 (three items), and cues to action (two items). All response items were on a four-point scale ranging from 'strongly agree' to 'strongly disagree'. For analysis purposes, all responses were coded as either 'agree' (responses included: 'strongly agree' and 'agree') or 'disagree' (responses included: 'strongly disagree' and 'disagree').

Perceived benefits of a COVID-19 vaccine: Perceived benefits were queried using two items. All response items were rated on a four-point scale ranging from 'strongly agree' to 'strongly disagree'. Similar to perceived susceptibility to and severity of COVID19, all responses were coded as either 'agree' or 'disagree'. In addition to perceived benefits of a COVID-19 vaccine, respondents were also asked to rate--on a four-point scale ranging from 'strongly agree' to 'strongly disagree'-perceived barriers surrounding a COVID-19 vaccine (e.g., 'I worry about the possible side-effects of the COVID-19 vaccine.'; 'I worry 
medRxiv preprint doi: https://doi.org/10.1101/2021.09.11.21263428; this version posted September 15, 2021. The copyright holder for this preprint (which was not certified by peer review) is the author/funder, who has granted medRxiv a license to display the preprint in perpetuity.

It is made available under a CC-BY-NC-ND 4.0 International license .

about fake COVID-19 vaccines.'). For analysis purposes, all responses were coded as either

'agree' or 'disagree'.

Willingness to pay for COVID-19 vaccine: Willingness to pay (WTP) was measured using a one-item question ("What is the maximum amount you are willing to pay for two doses of the COVID-19 vaccine?") on an eight-point scale ('PHP500', 'PHP1,000', 'PHP1,500', 'PHP2,000', 'PHP2,500', 'PHP3,000', 'PHP3,500', and 'PHP4,000'). The price range options were based on the approximate minimum-maximum price range of current vaccines in the Philippines.

Confidence in an international COVID-19 vaccine: Participants were asked to rate their level of confidence in using a vaccine for COVID-19 made in China, Russia, and the USA or Europe on a four-point scale ('completely not confident', 'not confident', 'confident', and 'completely confident'). Preference for the nationality of a manufacturer of the COVID-19 vaccine was also inquired.

\section{Ethics Review and IRB Approval}

Our study protocol (Protocol Number 21-026) was reviewed and approved by the

Institutional Review Board of Providence College on January 15, 2021. An informed consent statement was included in the survey instrument to welcome respondents who had clicked on the anonymous survey link provided by Qualtrics. 
medRxiv preprint doi: https://doi.org/10.1101/2021.09.11.21263428; this version posted September 15, 2021. The copyright holder for this preprint (which was not certified by peer review) is the author/funder, who has granted medRxiv a license to display the preprint in perpetuity.

It is made available under a CC-BY-NC-ND 4.0 International license .

\section{Statistical Analyses}

All statistical analyses were conducted using Statistical Package for the Social Sciences (SPSS) version 27. A $p$-value of less than .05 was considered statistically significant. Frequency tables, charts, and proportions were used for data summarizationproportions and their respective $95 \%$ confidence intervals (CI) were calculated for each predictor variable. The model fit of binary logistic regression analysis was calculated using the Hosmer-Lemeshow goodness-of-fit test (Hosmer, Lemeshow \& Sturdivant, 2013). Participant responses to the one-item intent to receive COVID-19 vaccine ('If a vaccine for COVID-19 is available in the Philippines, would you use it?') was coded into two categories: vaccine hesitant (responses included: 'definitely no', 'probably no', 'unsure') and not vaccine hesitant (responses included: 'probably yes', 'definitely yes'). The eight options of WTP for a COVID-19 vaccine were categorized into three categories (PHP5001,000, PHP1,500-2,500, PHP3,000-4,000). A multinomial logistic regression was employed to model factors associated with WTP for a COVID-19 vaccine with the lowest (PHP500$1,000)$ as the reference. We ran univariate analyses followed by a binary logistic regression analysis, including all factors showing significance $(p<.05)$, to determine which factors predicted individual intention to receive a COVID-19 vaccine. Only significant factors in the univariate analyses were included in the binary logistic regression analysis. 
medRxiv preprint doi: https://doi.org/10.1101/2021.09.11.21263428; this version posted September 15, 2021. The copyright holder for this preprint (which was not certified by peer review) is the author/funder, who has granted medRxiv a license to display the preprint in perpetuity.

It is made available under a CC-BY-NC-ND 4.0 International license .

\section{RESULTS}

\section{Demographics}

A total of 7,193 complete survey responses were received. Responses received represented participants with diverse demographics as shown in Table 1, and from all of the regions of the Philippines (Figure 1). The study sample had a higher representation of younger adults aged 18 to 30 years old (52.4\%), which is not unexpected given that our open access survey was deployed on social media. Additionally, the majority of participants identified as female (66.6\%), single (65.7\%), had obtained a college/university degree or above (84\%), and lived in an urban location (78.9\%). Only a small portion of the sample reported having an existing chronic condition (16.4\%) while $17.5 \%$ reported having either 'very poor', 'poor', or 'fair' health. Additionally, $72.8 \%$ of the sample reported knowing someone who had tested positive for COVID-19.

\section{Health Beliefs}

As displayed in Figure 2, with regards to perceived susceptibility to COVID-19 vaccines, the minority of participants reported that they thought that there was a high chance of personally contracting COVID-19 in the next few months (31.5\%). However, when prompted to report worry about the likelihood of getting COVID-19, the majority

of participants reported that they were worried (84.1\%) and that COVID-19 is a serious 
medRxiv preprint doi: https://doi.org/10.1101/2021.09.11.21263428; this version posted September 15, 2021. The copyright holder for this preprint (which was not certified by peer review) is the author/funder, who has granted medRxiv a license to display the preprint in perpetuity.

It is made available under a CC-BY-NC-ND 4.0 International license .

illness with life-threatening conditions (96.3\%). Furthermore, a significant majority (93.1\%) reported that they were afraid of getting COVID-19, and that they would get very sick if they were infected with the virus (75\%). The respondents in the survey reported significant perceived benefits for the COVID-19 vaccines. A large portion of participants noted that they believed that a COVID-19 vaccine would decrease the chances of getting COVID-19 (88.1\%) and that the vaccine would alleviate their anxieties about catching the virus (84.5\%). Notably, significant majorities of our respondents reported that they had worries about possible side-effects $(89.6 \%)$, effectiveness $(87.1 \%)$, safety $(88.8 \%)$, and high cost $(78 \%)$ of the vaccines. Nearly all were concerned about the possibility of fake jabs $(97.4 \%)$. Many participants noted they would only receive the COVID-19 vaccines after many others had received it $(72.8 \%)$ or after politicians had received it $(68.2 \%)$.

\section{COVID-19 Vaccination Intent}

Figure 3 shows the proportion of responses for intention to take a COVID-19 vaccine if one were available in the Philippines. A total of 4,497 of the participants $(62.5 \%)$ responded either 'probably yes' or 'definitely yes' to COVID-19 vaccine intentdemonstrating that they were not vaccine hesitant - while 2,696 (37.4\%) displayed vaccine hesitancy (responses included 'definitely no', 'probably no', and 'unsure'). More 
medRxiv preprint doi: https://doi.org/10.1101/2021.09.11.21263428; this version posted September 15, 2021. The copyright holder for this preprint (which was not certified by peer review) is the author/funder, who has granted medRxiv a license to display the preprint in perpetuity.

It is made available under a CC-BY-NC-ND 4.0 International license.

specifically, the majority of responses were 'probably yes' $(32.8 \%, \mathrm{n}=2,358)$, followed by 'definitely yes' $(29.7 \%, \mathrm{n}=2,139)$, 'unsure' $(28 \%, \mathrm{n}=2,017)$, 'probably no' $(6.4 \%, \mathrm{n}=$ 461), and 'definitely no' $(3 \%, \mathrm{n}=318)$. Demographics of respondents who intend (not vaccine hesitant) and do not intend (vaccine hesitant) to take a COVID-19 vaccine is displayed in Table 1.

Table 2 shows the univariate and binary analyses of factors associated with a vaccine hesitant and a not vaccine hesitant intention by demographics and health belief constructs. Univariate analyses showed a significantly higher proportion of participants who were single $(63.6 \%)$ expressed an intention to take a COVID-19 vaccine (not vaccine hesitant) than married participants (60.4\%). However, the association was not significant in the binary analysis. By occupational category, a significantly higher proportion of respondents that were not vaccine hesitant included those who identified as students $(65.5 \%)$ and professional/white collar workers (62\%). Significant differences were noted in vaccine hesitancy for COVID-19 by location, whereby individuals in an urban location $(65 \%)$ reported a higher proportion of an intention to vaccinate compared to respondents in rural locations $(53.1 \%)$.

By demographics, binary analyses revealed that males have greater odds of an intention to take a COVID-19 vaccine $(\mathrm{OR}=1.222,95 \%$ CI $[1.078-1.386])$ than females. Being self-employed $(\mathrm{OR}=.776,95 \% \mathrm{CI}[.586-1.026])$, a student $(\mathrm{OR}=1.352,95 \% \mathrm{CI}$ 
medRxiv preprint doi: https://doi.org/10.1101/2021.09.11.21263428; this version posted September 15, 2021. The copyright holder for this preprint (which was not certified by peer review) is the author/funder, who has granted medRxiv a license to display the preprint in perpetuity.

It is made available under a CC-BY-NC-ND 4.0 International license .

[1.046-1.749]), having a monthly income of less than PHP10,000 (OR $=.596,95 \%$ [CI, $.477-.745])$, PHP10,000-20,000 (OR = .587, 95\% CI [.465-.741]), and PHP20,000-100,000 $(\mathrm{OR}=.822,95 \% \mathrm{CI}[.679-.995])$ were also significant predictors of intent to vaccinate. Additionally, perceived overall health reported as 'fair', 'poor', and 'very poor' (OR = $.755,95 \%$ CI [.632-.903]), and 'good' (OR = 1.173, 95\% CI [1.024, 1.343]) were significant predictors of intent to vaccinate for COVID-19.

Most of the constructs of the HBM were significantly associated with an intention to take a COVID-19 vaccination in the univariate analyses. While $72.8 \%$ of participants reported they would only take the COVID-19 vaccine after many others receive it (Figure $3)$, disagreement with that notion $(\mathrm{OR}=1.894,95 \% \mathrm{CI}[1.597-2.247])$ was the strongest predictor for an intent to vaccinate. Intent to receive a COVID-19 vaccine only once politicians receive it $(\mathrm{OR}=1.411,95 \%$ CI $[1.214-1.640])$ was also a strong predictor of intention to take a COVID-19 vaccine.

\section{Willingness to Pay (WTP)}

Table 3 shows that most participants were willing to pay PHP1,000 [USD20.38] (21\%) followed by PHP500 [USD10.18] (18.8\%) for a COVID-19 vaccine. The median (interquartile range [IQR]) of WTP for a COVID-19 vaccine was PHP2,000 [USD40.73].

Table 4 shows the results of the univariate and multinomial regression analyses for the 
medRxiv preprint doi: https://doi.org/10.1101/2021.09.11.21263428; this version posted September 15, 2021. The copyright holder for this preprint (which was not certified by peer review) is the author/funder, who has granted medRxiv a license to display the preprint in perpetuity.

It is made available under a CC-BY-NC-ND 4.0 International license .

marginal WTP for an amount of PHP500/1,000 [USD10.18/20.36], PHP1,500/2,000/2,500

[USD30.55/40.73/50.91], PHP3000/3500/4000 [USD61.09/71.28/81.46] by demographics

and HBM constructs. The results of the multinomial logistic regression (PHP1,500/2,000/2,500 vs. PHP500/1,000 and PHP3,000/3,500/4,000 vs. PHP500/1,000)

revealed that individuals aged 31 to 40 displayed a higher WTP: PHP3,000/3,500/4,000

[USD61.09/71.28/81.46] over PHP500/1,000 [USD10.18/20.36]. Compared to married participants, single respondents had the highest WTP: PHP3,000/3,500/4,000 [USD61.09/71.28/81.46] over PHP500/1,000 [USD10.18/20.36]. Students had the highest WTP: PHP3,000/3,500/4,000 ([USD61.09/71.28/81.46] over PHP500/1,000 [USD10.18/20.36]. For monthly income, there was a gradual increase in the odds of WTP for an amount PHP1,500/2,000/2,500 [USD30.55/40.73/50.91] over PHP500/1,000 [USD10.18/20.36]. Participants in rural locations were WTP: PHP1,500/2,000/2,500 [USD30.55/40.73/50.91] over PHP500/1,000 [USD10.18/20.36]. For HBM constructs, similar to intent to vaccinate, a higher WTP was significantly associated with items in the perceived susceptibility to and severity of COVID-19, perceived benefits of a COVID19 vaccine, perceived barriers, and cues to action constructs. 
medRxiv preprint doi: https://doi.org/10.1101/2021.09.11.21263428; this version posted September 15, 2021. The copyright holder for this preprint (which was not certified by peer review) is the author/funder, who has granted medRxiv a license to display the preprint in perpetuity.

It is made available under a CC-BY-NC-ND 4.0 International license.

\section{Vaccine Brand Preference}

Figure 4 shows confidence in foreign-made (i.e., China, Russia, and the USA or Europe) COVID-19 vaccines. The vast majority of participants were 'confident' (59.7\%) or 'completely confident' $(23.1 \%)$ in a COVID-19 vaccine made in the USA or Europe. In contrast, a majority of participants indicated they were either 'completely not confident' $(38.2 \%, 16.5 \%)$ or 'not confident' $(46.8 \%, 49.2 \%)$ in a vaccine developed in China and Russia respectively. Findings on the preference of where a COVID-19 vaccine is made revealed respondents reported a preference for a vaccine made in the USA or Europe (53.4\%) while $44.6 \%$ of participants indicated no preference of where a COVID-19 vaccine is made as long as it is safe and effective.

\section{DISCUSSION}

In this study, we sought to interrogate the extent of COVID-19 vaccine hesitancy in the Philippines and to determine whether the Health Belief Model (HBM) could be used to explain this hesitancy among Filipinos. We deployed our nationwide open-access online survey for a two week period (January 15-29, 2021), a month before the first COVID-19 vaccines were administered in the archipelago on March 1, 2021.

We received nearly 7,200 completed surveys from around the country. The majority of responses $(5,348 ; 74 \%)$ were from the three geographical and administrative regions, 
medRxiv preprint doi: https://doi.org/10.1101/2021.09.11.21263428; this version posted September 15, 2021. The copyright holder for this preprint (which was not certified by peer review) is the author/funder, who has granted medRxiv a license to display the preprint in perpetuity.

It is made available under a CC-BY-NC-ND 4.0 International license .

National Capital Region (NCR), Region III, and Region IVA, that encompass and surround the capital city of Manila. Together, these three regions, which have $38 \%$ of the population, have weathered the worst of the COVID-19 pandemic in the Philippines with about $60 \%$ of the total nationwide reported cases (ncovtracker.doh.gov.ph).

A majority of our respondents $(62.5 \%)$ indicated that they were willing to be vaccinated by responding either 'probably yes' or 'definitely yes' to COVID-19 vaccine intent. As a point of comparison, a survey conducted by Pulse Asia from February 22, 2021, to March 3, 2021, which was a month after our survey period, reported that only $16 \%$ of the 2,400 Filipinos they interviewed face-to-face indicated that they would have themselves vaccinated, while $23 \%$ said that they "cannot say" if they would have themselves vaccinated (Pulse Asia, 2021).

There are many possible reasons for this difference in reported vaccine confidence but three immediately come to mind. First, our survey was an open access online survey while the Pulse Asia survey involved face-to-face interviews of Filipinos throughout the country. By their very nature, online surveys are not representative of the population at large because access to the internet is uneven, especially in developing countries. Second, the respondents of our survey were skewed in favor of individuals living in those urban centers around the capital that have endured the most stringent quarantine restrictions of the pandemic. It is likely that this pandemic experience would have heightened their 
medRxiv preprint doi: https://doi.org/10.1101/2021.09.11.21263428; this version posted September 15, 2021. The copyright holder for this preprint (which was not certified by peer review) is the author/funder, who has granted medRxiv a license to display the preprint in perpetuity.

It is made available under a CC-BY-NC-ND 4.0 International license .

desire to be vaccinated as compared to those Filipinos who live in the countryside where viral transmission was sporadic and pandemic restrictions were relatively innocuous. Notably, our bivariate analysis confirms that individuals in an urban location (65\%) reported a higher proportion of an intention to vaccinate compared to respondents in rural locations $(53.1 \%)$. Finally, the intervening month between the two surveys witnessed several political events prior to the vaccine rollout that could have changed the public's views on the COVID-19 vaccines. Most significantly, on February 26, 2021, President Rodrigo R. Duterte signed into law a bill giving indemnity to vaccine makers should their vaccines cause serious adverse side effects among recipients. The bill was criticized by several senators of the Philippines who described it as a desperate move on the part of the Duterte administration. This political squabble could have decreased public confidence in the safety of the COVID-19 vaccines.

Multivariable analysis revealed that HBM constructs were associated with vaccination intention in the Philippines, which is in accordance with other studies from the Asia-Pacific region (Wong et al., 2020, 2021; Lin et al., 2020; Yu et al., 2021; Kabir et al., 2021; Huynh et al., 2021; Tao, Wang \& Liu, 2021) Perceptions of high susceptibility, high severity, and significant benefits were all good predictors for vaccination intent. A study to interrogate vaccine hesitancy among Filipinos in two urban communities in Manila before the COVID-19 pandemic also found that respondents who believed in the 
medRxiv preprint doi: https://doi.org/10.1101/2021.09.11.21263428; this version posted September 15, 2021. The copyright holder for this preprint (which was not certified by peer review) is the author/funder, who has granted medRxiv a license to display the preprint in perpetuity.

It is made available under a CC-BY-NC-ND 4.0 International license.

protective nature of vaccines were less likely to report vaccine hesitancy and were nine times less likely to refuse vaccination for their children because of negative media exposure (Migriño et al., 2020).

Perceived barriers against COVID-19 immunization reported by our respondents including worries about the side-effects, effectiveness, and safety of the vaccines have also been reported by these other HBM studies. These are triggers for hesitancy that can be eradicated with scientific explanation. Public health authorities in the Philippines should address these issues. In response to the findings of this survey, we have initiated a public awareness campaign in the Philippines to directly respond to these concerns by generating infographics and other publication materials to alleviate these worries (https://www.facebook.com/USTCoVAX/).

Interestingly, we discovered that our Filipino respondents were overwhelmingly worried about fake COVID-19 vaccines (97.4\%). Similar concerns have been raised in India (Choudhary et al., 2021) though this was not observed in China (Lin et al., 2020). This suggests that the national governments of developing countries should ensure the integrity of the vaccine rollout to reassure their citizens that they are not receiving "dud" doses.

Next, we found that external cues to action were important. Large majorities of our respondents would only receive the COVID-19 vaccines after many others had received 
medRxiv preprint doi: https://doi.org/10.1101/2021.09.11.21263428; this version posted September 15, 2021. The copyright holder for this preprint (which was not certified by peer review) is the author/funder, who has granted medRxiv a license to display the preprint in perpetuity.

It is made available under a CC-BY-NC-ND 4.0 International license .

it $(72.8 \%)$ or after politicians had received it $(68.2 \%)$. We observed that disagreement with the statement that the individual would receive the COVID-19 vaccine only after many others had received it was the strongest predictor for an intent to vaccinate among our Filipino respondents. This segment of the population could represent citizens who so want to be vaccinated that they are willing to put aside the collectivist mindset that is strongly rooted in Filipino culture (Grimm et al., 1999). However, given the high numbers of respondents who indicated that they were waiting for others to first receive the vaccine, our UST-CoVAX public awareness program began sharing the personal vaccination testimonies of Filipinos around the world on social media platforms to show Filipinos in the Philippines that others like them had already received the COVID-19 vaccines (https://www.facebook.com/USTCoVAX/).

Our study revealed that most $(21 \%)$ were willing to pay an amount of PHP1,000 [USD20] for the COVID-19 vaccines with an average willing-to-pay amount of PHP1,892 [USD38]. Multinomial logistic regression showed that individuals aged 31 to 40, single respondents, and students had the highest WTP in their demographic categories respectively. Since the minimum daily wage in the Philippines in 2021 is PHP537 [USD10.54], the average WTP amount of PHP1,892 [USD38] remains a significant investment in the health of the individual, equivalent to nearly four days of wages. This 
medRxiv preprint doi: https://doi.org/10.1101/2021.09.11.21263428; this version posted September 15, 2021. The copyright holder for this preprint (which was not certified by peer review) is the author/funder, who has granted medRxiv a license to display the preprint in perpetuity.

It is made available under a CC-BY-NC-ND 4.0 International license.

suggests that the COVID-19 vaccines should be provided free of charge to ensure population-wide access among all Filipinos across the economic classes.

Finally, our analysis revealed significant vaccine brand preference among our Filipino respondents. The vast majority of participants were 'confident' (59.7\%) or 'completely confident' $(23.1 \%)$ in a COVID-19 vaccine made in the USA or Europe. In contrast, a majority of participants indicated they were either 'completely not confident' $(38.2 \%, 16.5 \%)$ or 'not confident' $(46.8 \%, 49.2 \%)$ in a vaccine developed in China and Russia respectively. These findings mirror those reported by the Pulse Asia survey already described above that showed that a majority (52\%) of Filipinos who were opting to get vaccinated preferred the Pfizer vaccine (Pulse Asia, 2021). This vaccine preference has to be managed by the national government to prevent Filipinos from unnecessarily delaying immunization to obtain their preferred vaccine brand.

Our study has several limitations. As we already noted above, the use of an openaccess online survey may result in sampling bias so we cannot generalize our findings to the entire Filipino population (Wyatt, 2000; Eysenbach \& Wyatt, 2002). It is notable that young people aged 18-30 years, who make up around $28 \%$ of the population of the Philippines (https://www.populationpyramid.net/philippines/), constitute $52.4 \%$ of our respondents. Unexpectedly, however, senior citizens aged 61-89 years of age, who constitute $8 \%$ of the country's population are also over-represented with $11.8 \%$ of the 
medRxiv preprint doi: https://doi.org/10.1101/2021.09.11.21263428; this version posted September 15, 2021. The copyright holder for this preprint (which was not certified by peer review) is the author/funder, who has granted medRxiv a license to display the preprint in perpetuity.

It is made available under a CC-BY-NC-ND 4.0 International license.

respondents. Furthermore, the responses were based on self-report and may be subject to self-reporting bias and a tendency to report socially desirable responses especially in a strongly collectivist society like the Philippines. One final limitation of our study is the bias associated with the assessment of acceptance and WTP for a hypothetical COVID19 vaccine before any concrete vaccines actually exist (Schmidt \& Bijmolt, 2019). We therefore intend to undertake a follow-up survey once the vaccine rollout in the country has stabilized. Nonetheless, despite these shortcomings, we believe that our findings will provide insights to support the vaccine rollout of the COVID-19 vaccines in the Philippines by helping public health authorities to understand vaccine demand and vaccine hesitancy in the country. Indeed, based on these findings, we inaugurated the UST-CoVAX public awareness campaign that seeks to increase vaccine confidence in the

Philippines by addressing the specific fears and concerns of our Filipino respondents and by sharing the personal vaccination testimonies of Filipinos around the world. (https://www.facebook.com/USTCoVAX/). 
medRxiv preprint doi: https://doi.org/10.1101/2021.09.11.21263428; this version posted September 15, 2021. The copyright holder for this preprint (which was not certified by peer review) is the author/funder, who has granted medRxiv a license to display the preprint in perpetuity.

It is made available under a CC-BY-NC-ND 4.0 International license .

\section{REFERENCES}

Alfonso C., Dayrit M., Mendoza R., Ong M. 2021. From Dengvaxia to Sinovac: Vaccine Hesitancy in the Philippines. The Diplomat.

Banik R., Islam MS., Pranta MUR., Rahman QM., Rahman M., Pardhan S., Driscoll R., Hossain S., Sikder MT. 2021. Understanding the determinants of COVID-19 vaccination intention and willingness to pay: findings from a population-based survey in Bangladesh. BMC Infectious Diseases 21:892. DOI: 10.1186/s12879-02106406-y.

Brewer NT., Chapman GB., Gibbons FX., Gerrard M., McCaul KD., Weinstein ND. 2007. Meta-analysis of the relationship between risk perception and health behavior: The example of vaccination. Health Psychology 26:136-145. DOI: 10.1037/02786133.26.2.136.

Burki T. 2020. Outbreak of coronavirus disease 2019. Lancet Infect Dis 20:292-293.

Case JB., Winkler ES., Errico JM., Diamond MS. 2021. On the road to ending the COVID-19 pandemic: Are we there yet? Virology 557:70-85. DOI:

10.1016/j.virol.2021.02.003.

Chen IH., Hsu SM., Wu JSJ., Wang YT., Lin YK., Chung MH., Huang PH., Miao NF. 2019. Determinants of nurses' willingness to receive vaccines: Application of the health belief model. Journal of Clinical Nursing 28:3430-3440. DOI: 
medRxiv preprint doi: https://doi.org/10.1101/2021.09.11.21263428; this version posted September 15, 2021. The copyright holder for this preprint (which was not certified by peer review) is the author/funder, who has granted medRxiv a license to display the preprint in perpetuity.

It is made available under a CC-BY-NC-ND 4.0 International license .

10.1111/jocn.14934.

Choudhary OP., Priyanka., Singh I., Mohammed TA., Rodriguez-Morales AJ. 2021.

Fake COVID-19 vaccines: scams hampering the vaccination drive in India and possibly other countries. Human Vaccines and Immunotherapeutics. DOI:

$10.1080 / 21645515.2021 .1960770$.

Donadiki EM., Jiménez-García R., Hernández-Barrera V., Sourtzi P., Carrasco-Garrido P., López de Andrés A., Jimenez-Trujillo I., Velonakis EG. 2014. Health Belief Model applied to non-compliance with HPV vaccine among female university students. Public Health 128:268-273. DOI: 10.1016/j.puhe.2013.12.004.

Eysenbach G., Wyatt J. 2002. Using the Internet for surveys and health research. Journal of Medical Internet Research 4:76-94. DOI: 10.2196/JMIR.4.2.E13.

Grimm SD., Church AT., Katigbak MS., Reyes JA. 1999. Self-Described Traits, Values, and Moods Associated with Individualism and Collectivism Testing I-C Theory in an Individualistic (U.S.) and a Collectivistic (Philippine) Culture. Journal of CrossCultural Psychology 30:466-500.

Guan WJ., Ni ZY., Hu Y., Liang WH., Ou CQ., He JX., Liu L., Shan H., Lei CL., Hui DSC., Du B., Li LJ., Zeng G., Yuen KY., Chen RC., Tang CL., Wang T., Chen PY., Xiang J., Li SY., Wang JL., Liang ZJ., Peng YX., Wei L., Liu Y., Hu YH., Peng P., Wang JM., Liu JY., Chen Z., Li G., Zheng ZJ., Qiu SQ., Luo J., Ye CJ., 
medRxiv preprint doi: https://doi.org/10.1101/2021.09.11.21263428; this version posted September 15, 2021. The copyright holder for this preprint (which was not certified by peer review) is the author/funder, who has granted medRxiv a license to display the preprint in perpetuity. It is made available under a CC-BY-NC-ND 4.0 International license .

Zhu SY., Zhong NS. 2020. Clinical Characteristics of Coronavirus Disease 2019 in China. The New England journal of medicine 382:1708-1720. DOI:

10.1056/NEJMoa2002032.

Hosmer DWJ., Lemeshow S., Sturdivant R. 2013. Applied Logistic Regression. Hoboken, NJ: John Wiley \& Sons, Inc.

Hu Y., Wang Y., Liang H., Chen Y. 2017. Seasonal influenza vaccine acceptance among pregnant women in zhejiang province, china: Evidence based on health belief model. International Journal of Environmental Research and Public Health 14. DOI: 10.3390/ijerph14121551.

Huynh G., Nguyen HTN., Nguyen VT., Pham A Le. 2021. Development and Psychometric Properties of the Health Belief Scales Toward COVID-19 Vaccine in Ho Chi Minh City, Vietnam. Risk management and healthcare policy 14:2517-2526.

DOI: $10.2147 /$ RMHP.S301645.

Inter-Agency Task Force for the Management of Emerging Infectious Disease. 2021. The Philippine National COVID-19 Vaccination Deployment Plan / Department of Health website.

Kabir R., Mahmud I., Chowdhury MTH., Vinnakota D., Jahan SS., Siddika N., Isha SN., Nath SK., Hoque Apu E. 2021. COVID-19 Vaccination Intent and Willingness to Pay in Bangladesh: A Cross-Sectional Study. Vaccines 9. DOI: 
medRxiv preprint doi: https://doi.org/10.1101/2021.09.11.21263428; this version posted September 15, 2021. The copyright holder for this preprint (which was not certified by peer review) is the author/funder, who has granted medRxiv a license to display the preprint in perpetuity. It is made available under a CC-BY-NC-ND 4.0 International license .

$10.3390 /$ vaccines 9050416 .

Lin Y., Hu Z., Zhao Q., Alias H., Danaee M., Wong LP. 2020. Understanding COVID19 vaccine demand and hesitancy: A nationwide online survey in China. PLoS neglected tropical diseases 14:e0008961. DOI: 10.1371/journal.pntd.0008961.

Mahmud I., Kabir R., Rahman MA., Alradie-Mohamed A., Vinnakota D., AlMohaimeed A. 2021. The health belief model predicts intention to receive the covid19 vaccine in saudi arabia: Results from a cross-sectional survey. Vaccines 9 . DOI: $10.3390 /$ vaccines 9080864 .

Migriño J., Gayados B., Birol KRJ., De Jesus L., Lopez CW., Mercado WC., Tolosa JMC., Torreda J., Tulagan G. 2020. Factors affecting vaccine hesitancy among families with children 2 years old and younger in two urban communities in Manila, Philippines. Western Pacific surveillance and response journal: WPSAR 11:20-26.

DOI: $10.5365 /$ wpsar.2019.10.2.006.

Novelli G., Biancolella M., Mehrian-Shai R., Colona VL., Brito AF., Grubaugh ND., Vasiliou V., Luzzatto L., Reichardt JKV. 2021. COVID-19 one year into the pandemic: from genetics and genomics to therapy, vaccination, and policy. Human Genomics 15. DOI: 10.1186/s40246-021-00326-3.

Paules C., Marston H., Fauci A. 2020. Coronavirus infections-more than just the common cold. JAMA 323:707. 
medRxiv preprint doi: https://doi.org/10.1101/2021.09.11.21263428; this version posted September 15, 2021. The copyright holder for this preprint (which was not certified by peer review) is the author/funder, who has granted medRxiv a license to display the preprint in perpetuity.

It is made available under a CC-BY-NC-ND 4.0 International license .

Pulse Asia. 2021.February 2021 Nationwide Survey on COVID-19. Available at https://www.pulseasia.ph/february-2021-nationwide-survey-on-covid-19/

Rappuoli R., Pizza M., Del Giudice G., De Gregorio E. 2014. Vaccines, new

opportunities for a new society. Proceedings of the National Academy of Sciences

of the United States of America 111:12288-12293. DOI: 10.1073/pnas.1402981111.

Rosenstock IM., Strecher VJ., Becker MH. 1988. Social Learning Theory and the Health Belief Model. Health Education \& Behavior 15:175-183. DOI:

$10.1177 / 109019818801500203$.

Sathyanarayana SD., Fernandes SD., Castelino LJ., Vadakkepushpakath AN., Shriram RG. 2020. Vaccines in the United States: a systematic review on history of evolution, regulations, licensing, and future challenges. Clinical and experimental vaccine research 9:69-75. DOI: 10.7774/cevr.2020.9.2.69.

Schmidt J., Bijmolt THA. 2019. Accurately measuring willingness to pay for consumer goods: a meta-analysis of the hypothetical bias. Journal of the Academy of Marketing Science 2019 48:3 48:499-518. DOI: 10.1007/S11747-019-00666-6.

Shahrabani S., Benzion U. 2010. Workplace vaccination and other factors impacting influenza vaccination decision among employees in Israel. International Journal of Environmental Research and Public Health 7:853-869. DOI: 10.3390/ijerph7030853.

Shahrabani S., Benzion U., Yom Din G. 2009. Factors affecting nurses' decision to get 
medRxiv preprint doi: https://doi.org/10.1101/2021.09.11.21263428; this version posted September 15, 2021. The copyright holder for this preprint (which was not certified by peer review) is the author/funder, who has granted medRxiv a license to display the preprint in perpetuity.

It is made available under a CC-BY-NC-ND 4.0 International license .

the flu vaccine. European Journal of Health Economics 10:227-231. DOI:

$10.1007 / \mathrm{s} 10198-008-0124-3$.

Shmueli L. 2021. Predicting intention to receive COVID-19 vaccine among the general population using the health belief model and the theory of planned behavior model. BMC public health 21:804. DOI: 10.1186/S12889-021-10816-7.

Tao L., Wang R., Liu J. 2021. Comparison of Vaccine Acceptance Between COVID-19 and Seasonal Influenza Among Women in China: A National Online Survey Based on Health Belief Model. Frontiers in medicine 8:679520. DOI:

10.3389/fmed.2021.679520.

Teitler-Regev S., Shahrabani S., Benzion U. 2011. Factors Affecting Intention among Students to Be Vaccinated against A/H1N1 Influenza: A Health Belief Model Approach. Advances in Preventive Medicine 2011:1-8. DOI: 10.4061/2011/353207.

Tsutsui Y., Benzion U., Shahrabani S. 2012. Economic and behavioral factors in an individual's decision to take the influenza vaccination in Japan. Journal of SocioEconomics 41:594-602. DOI: 10.1016/j.socec.2012.05.001.

Wong LP., Alias H., Wong PF., Lee HY., AbuBakar S. 2020. The use of the health belief model to assess predictors of intent to receive the COVID-19 vaccine and willingness to pay. Human Vaccines and Immunotherapeutics 16:2204-2214. DOI: $10.1080 / 21645515.2020 .1790279$ 
medRxiv preprint doi: https://doi.org/10.1101/2021.09.11.21263428; this version posted September 15, 2021. The copyright holder for this preprint (which was not certified by peer review) is the author/funder, who has granted medRxiv a license to display the preprint in perpetuity. It is made available under a CC-BY-NC-ND 4.0 International license .

Wong MCS., Wong ELY., Huang J., Cheung AWL., Law K., Chong MKC., Ng RWY., Lai CKC., Boon SS., Lau JTF., Chen Z., Chan PKS. 2021. Acceptance of the COVID-19 vaccine based on the health belief model: A population-based survey in Hong Kong. Vaccine 39:1148-1156. DOI: 10.1016/j.vaccine.2020.12.083.

Wyatt JC. 2000. When to use web-based surveys. Journal of the American Medical Informatics Association 7:426-430. DOI: 10.1136/jamia.2000.0070426.

Xie J., Tong Z., Guan X., Du B., Qiu H. 2020. Clinical Characteristics of Patients Who Died of Coronavirus Disease 2019 in China. JAMA network open 3:e205619. DOI: 10.1001/jamanetworkopen.2020.5619.

Yu Y., Lau JTF., She R., Chen X., Li L., Li L., Chen X. 2021. Prevalence and associated factors of intention of COVID-19 vaccination among healthcare workers in China: application of the Health Belief Model. Human Vaccines and Immunotherapeutics. DOI: 10.1080/21645515.2021.1909327.

Zhu N., Zhang D., Wang W., al. et. 2020. A novel coronavirus from patients with pneumonia in China, 2019. N Engl J Med 382:727-733. 


\begin{tabular}{|c|c|c|}
\hline $\begin{array}{c}\text { REGION OF THE } \\
\text { PHILIPPINES }\end{array}$ & $\begin{array}{c}\text { Number of } \\
\text { Responses } \\
\text { (n) }\end{array}$ & $\begin{array}{c}\text { Percent of } \\
\text { Responses } \\
(\%)\end{array}$ \\
\hline BARMM & 15 & $0.2 \%$ \\
CAR & 41 & $0.6 \%$ \\
NCR & 3,602 & $50.1 \%$ \\
\hline Region I & 131 & $1.8 \%$ \\
\hline Region II & 125 & $1.7 \%$ \\
\hline Region III & 722 & $10 \%$ \\
\hline Region N-A & 1,024 & $14.2 \%$ \\
\hline Region N-B & 56 & $0.8 \%$ \\
\hline Region IX & 52 & $0.7 \%$ \\
\hline Region V & 92 & $1.3 \%$ \\
\hline Region VI & 456 & $6.3 \%$ \\
\hline Region VII & 504 & $7 \%$ \\
\hline Region VIII & 85 & $1.2 \%$ \\
\hline Region X & 141 & $2 \%$ \\
\hline Region XI & 79 & $1.1 \%$ \\
\hline Region XII & 41 & $0.6 \%$ \\
\hline Region XIII & 14 & $0.2 \%$ \\
\hline No Region Listed & 13 & $0.2 \%$ \\
\hline
\end{tabular}


Respondents' Health Beliefs Regarding COVID-19 and its Vaccines

PERCEIVED SUSCEPTIBILITY Worried about the likelihood of getting COVID-19

PERCEIVED SEVERITY

COVID-19 is serious with life threatening conditions

I will be vory sick if I get COVID-19

I am afraid of getting COVID.19

PERCEIVED BENEFITS

Vaccination will decrease my chances of getting COVID 19 Vaceination will decrease my worries about catching COVID-19

PERCEIVED BARRIERS

I worry about the possible side-effects of the COVID-19 vaccine

I worry about the effectiveness of the COVID-19 vaccine I worry about the safety of the COVID-19 vaccine

I worry about the high cost of the COVID-19 vaccine

I worry about fake COVID-19 vaccines

I worry that the COVID-19 vaccines will make me sick I worry the COVID-19 vaccines will not be effective against new virus variants

CUES TO ACTION

I will only receive the COVID-19 vaccines after many others receive it

I will only receive the COVID-19 vaceines after politieians receive it

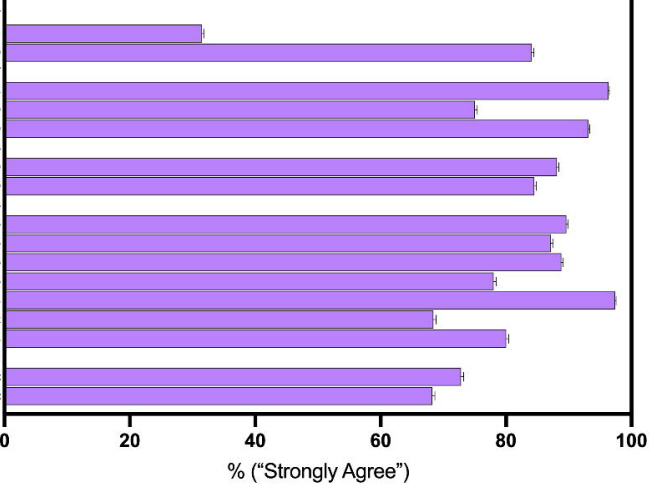




\section{COVID-19 Vaccination Intent}

$(n=7,193)$

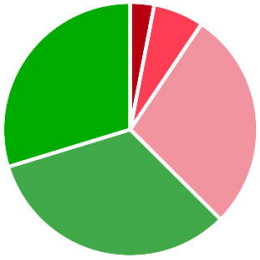

Definitely No ( $n=218 ; 3 \%)$

Probably No ( $n=461 ; 6.4 \%)$

Unsure ( $n=2,017 ; 28 \%$ )

Probably Yes ( $n=2,358 ; 32.8 \%$ )

Definitely Yes ( $n=2,139 ; 29.7 \%)$ 
Confidence in a Russian Vaccine ( $n=7,913$ )

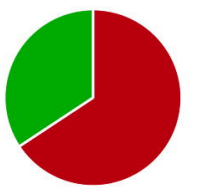

Not Confident ( $n=4,726 ; 65.7 \%)$ Confident $(n=2,467 ; 34.3 \%)$
Confidence in a Chinese Vaccine ( $n=7,193)$

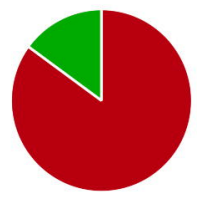

- Not Confident $(\mathrm{n}=6,118 ; 85 \%)$

Confident $(n=1,075 ; 15 \%)$
Confidence in a USA or European Vaccine $(n=7,193)$

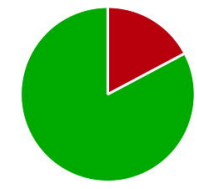

- Not Confident ( $n=1,241 ; 17.3 \%)$ Confident ( $n=5,952 ; 82.3 \%)$ 
medRxiv preprint doi: https://doi.org/10.1101/2021.09.11.21263428; this version posted September 15, 2021. The copyright holder for this preprint (which was not certified by peer review) is the author/funder, who has granted medRxiv a license to display the preprint in perpetuity.

It is made available under a CC-BY-NC-ND 4.0 International license .

Table 1. Demographics and COVID-19 Vaccine intent $(\mathrm{N}=7,193)$.

\begin{tabular}{|c|c|c|c|}
\hline & \multirow[b]{2}{*}{ Overall N (\%) } & \multicolumn{2}{|c|}{$\begin{array}{l}\text { If a vaccine for COVID-19 is available in the Philippines, would } \\
\text { you use it? }\end{array}$} \\
\hline & & $\begin{array}{c}\text { Vaccine hesitant } \\
\text { (Definitely no/Probably } \\
\text { no/Unsure) } \\
\mathrm{n}=2696(\%)\end{array}$ & $\begin{array}{c}\text { Not vaccine hesitant } \\
\text { (Probably yes/Definitely } \\
\text { yes) } \\
\mathrm{n}=4497(\%)\end{array}$ \\
\hline \multicolumn{4}{|l|}{ Demographics } \\
\hline \multicolumn{4}{|l|}{ Age group (years) } \\
\hline $18-30$ & $3770(52.4)$ & $1405(37.3)$ & $2365(62.7)$ \\
\hline $31-40$ & $815(11.3)$ & $306(37.5)$ & $509(62.5)$ \\
\hline $41-50$ & $861(12)$ & $335(38.9)$ & $526(61.1)$ \\
\hline $51-60$ & $900(12.5)$ & $326(36.2)$ & $574(63.8)$ \\
\hline $61-89$ & $847(11.8)$ & $324(38.3)$ & $523(61.7)$ \\
\hline \multicolumn{4}{|l|}{ Gender } \\
\hline Female & $4789(66.6)$ & $1955(40.8)$ & $2834(59.2)$ \\
\hline Male & $2404(33.4)$ & $741(30.8)$ & $1663(69.2)$ \\
\hline \multicolumn{4}{|l|}{ Marital Status } \\
\hline Single & $4724(65.7)$ & $1719(36.4)$ & 3005 (63.6) \\
\hline Married & $2469(34.3)$ & 977 (39.6) & $1492(60.4)$ \\
\hline \multicolumn{4}{|l|}{ Highest Education Level } \\
\hline Elementary school or below & 1 & 1 & \\
\hline Junior high school & $46(.6)$ & $29(63)$ & $17(37)$ \\
\hline Senior high school & $1102(15.3)$ & $378(34.3)$ & $724(65.7)$ \\
\hline College/university of above & $6044(84)$ & $2288(37.9)$ & $3756(62.1)$ \\
\hline \multicolumn{4}{|l|}{ Occupation } \\
\hline Blue collar worker & $91(1.3)$ & $42(46.2)$ & $49(53.8)$ \\
\hline Profession/white collar worker & $2980(41.4)$ & $1133(38)$ & $1847(62)$ \\
\hline Self-employed & $575(8)$ & $254(44.2)$ & $321(55.8)$ \\
\hline Student & $2831(39.4)$ & $976(34.5)$ & $1855(65.5)$ \\
\hline Housewife/retired/unemployed/other & $716(10)$ & $291(40.6)$ & $425(59.4)$ \\
\hline \multicolumn{4}{|l|}{ Monthly Income (PHP) } \\
\hline$\leq 10,000$ & $2583(35.9)$ & $1004(38.9)$ & $1579(61.1)$ \\
\hline $10,000-20,000$ & $954(13.3)$ & $468(49.1)$ & $486(50.9)$ \\
\hline $20,000-100,000$ & $2517(35)$ & $907(36)$ & $1610(64)$ \\
\hline$\geq 100,000$ & $1139(15.8)$ & $317(27.8)$ & $822(72.2)$ \\
\hline \multicolumn{4}{|l|}{ Location } \\
\hline Urban & $5676(78.9)$ & $1985(35)$ & $3691(65)$ \\
\hline Rural & $1517(21.1)$ & $711(46.9)$ & $806(53.1)$ \\
\hline \multicolumn{4}{|l|}{ Ever tested positive for COVID-19 } \\
\hline Yes & $211(2.9)$ & $68(32.2)$ & $143(67.8)$ \\
\hline No & $6982(97.1)$ & $2628(37.6)$ & $4354(62.4)$ \\
\hline $\begin{array}{l}\text { Know anyone who has tested positive for } \\
\text { COVID-19 }\end{array}$ & & & \\
\hline
\end{tabular}


medRxiv preprint doi: https://doi.org/10.1101/2021.09.11.21263428; this version posted September 15, 2021. The copyright holder for this preprint (which was not certified by peer review) is the author/funder, who has granted medRxiv a license to display the preprint in perpetuity.

It is made available under a CC-BY-NC-ND 4.0 International license .

\begin{tabular}{|l|c|c|c|}
\hline Yes & $5234(72.8)$ & $1780(34)$ & $3454(66)$ \\
\hline No & $1959(27.2)$ & $916(46.8)$ & $1043(53.2)$ \\
\hline Have an existing chronic condition & & & \\
\hline Yes & $1178(16.4)$ & $396(33.6)$ & $782(66.4)$ \\
\hline No & $6015(83.6)$ & $2300(38.2)$ & $3715(61.8)$ \\
\hline Perceived overall health & & & \\
\hline Very good & $1997(27.8)$ & $802(40.2)$ & $1195(59.8)$ \\
\hline Good & $3934(54.7)$ & $1376(35)$ & $2558(65)$ \\
\hline Fair/Poor/Very poor & $1262(17.5)$ & $518(41)$ & $744(59)$ \\
\hline
\end{tabular}


medRxiv preprint doi: https://doi.org/10.1101/2021.09.11.21263428; this version posted September 15, 2021. The copyright holder for this preprint (which was not certified by peer review) is the author/funder, who has granted medRxiv a license to display the preprint in perpetuity.

It is made available under a CC-BY-NC-ND 4.0 International license .

Table 2. Demographics, Characteristics, and Factors associated with an Intention to take the COVID-19 Vaccine $(N=7,193)$

\begin{tabular}{|c|c|c|c|c|c|c|c|}
\hline & & \multicolumn{3}{|c|}{ Univariable analysis } & \multirow[b]{2}{*}{$p$-value } & \multirow{2}{*}{$\begin{array}{c}\text { Multivariable } \\
\text { logistic regression }\end{array}$} & \multirow[b]{2}{*}{$p$-value } \\
\hline & $\begin{array}{l}\text { Overall } \\
\mathrm{N}(\%)\end{array}$ & $\begin{array}{c}\text { Vaccine } \\
\text { hesitant } \\
\mathrm{n}=2696\end{array}$ & $\begin{array}{c}\text { Not } \\
\text { vaccine } \\
\text { hesitant } \\
\mathrm{n}=4497\end{array}$ & $\begin{array}{c}\text { Unadjusted } \\
\text { OR [95\% } \\
\text { CI] }\end{array}$ & & & \\
\hline \multicolumn{8}{|l|}{ Demographics } \\
\hline \multicolumn{8}{|l|}{ Age group (years) } \\
\hline $18-30$ & $\begin{array}{l}3770 \\
(52.4)\end{array}$ & $\begin{array}{l}1405 \\
(37.3)\end{array}$ & $\begin{array}{l}2365 \\
(62.7)\end{array}$ & Reference & & & \\
\hline $31-40$ & $\begin{array}{l}815 \\
(11.3) \\
\end{array}$ & $306(37.5)$ & $509(62.5)$ & $\begin{array}{l}1.043[.894, \\
1.216]\end{array}$ & .800 & & \\
\hline $41-50$ & $\begin{array}{l}861 \\
(12)\end{array}$ & $335(38.9)$ & $526(61.1)$ & $1.030[8.45$ & & & \\
\hline $51-60$ & $\begin{array}{l}900 \\
(12.5)\end{array}$ & $326(36.2)$ & $574(63.8)$ & $\begin{array}{l}.973[.800, \\
1.182]\end{array}$ & & & \\
\hline $61-89$ & $\begin{array}{l}847 \\
(11.8) \\
\end{array}$ & $324(38.3)$ & $523(61.7)$ & $\begin{array}{l}1.091[.898 \\
1.324]\end{array}$ & & & \\
\hline \multicolumn{8}{|l|}{ Gender } \\
\hline Female & $\begin{array}{l}4789 \\
(66.6) \\
\end{array}$ & $\begin{array}{l}1955 \\
(40.8) \\
\end{array}$ & $\begin{array}{l}2834 \\
(59.2)\end{array}$ & $\begin{array}{l}.646[.582, \\
.717]\end{array}$ & $<.001$ & Reference & \\
\hline Male & $\begin{array}{l}2404 \\
(33.4) \\
\end{array}$ & $741(30.8)$ & $\begin{array}{l}1663 \\
(69.2) \\
\end{array}$ & & & $1.223[1.078,1.386]$ & .002 \\
\hline \multicolumn{8}{|l|}{ Marital Status } \\
\hline Single & $\begin{array}{l}4724 \\
(65.7)\end{array}$ & $\begin{array}{l}1719 \\
(36.4)\end{array}$ & $\begin{array}{l}3005 \\
(63.6)\end{array}$ & & & $1.098[.939,1.286]$ & .242 \\
\hline Married & $\begin{array}{l}2469 \\
(34.3) \\
\end{array}$ & $977(39.6)$ & $\begin{array}{l}1492 \\
(60.4) \\
\end{array}$ & $\begin{array}{l}.874[.790, \\
.966]\end{array}$ & .008 & Reference & \\
\hline \multicolumn{8}{|l|}{ Highest Education Level } \\
\hline Elementary school or below & 1 & 1 & \multicolumn{5}{|c|}{$n$ too small to calculate } \\
\hline Junior high school & $46(.6)$ & $29(63)$ & $17(37)$ & $\begin{array}{l}2.80[1.535, \\
5.107]\end{array}$ & $<.001$ & $.465[.234, .924]$ & .029 \\
\hline Senior high school & $\begin{array}{l}1102 \\
(15.3)\end{array}$ & $378(34.3)$ & $724(65.7)$ & $\begin{array}{l}.857[.749, \\
.981]\end{array}$ & & $1.064[.886,1.277]$ & .506 \\
\hline College/university of above & $\begin{array}{l}6044 \\
(84)\end{array}$ & $\begin{array}{l}2288 \\
(37.9) \\
\end{array}$ & $\begin{array}{l}3756 \\
(62.1) \\
\end{array}$ & Reference & & Reference & \\
\hline \multicolumn{8}{|l|}{ Occupation } \\
\hline Blue collar worker & $91(1.3)$ & $42(46.2)$ & $49(53.8)$ & $\begin{array}{l}1.252[.808, \\
1.940]\end{array}$ & $<.001$ & $1.057[.624,1.789]$ & .837 \\
\hline Profession/white collar worker & $\begin{array}{l}2980 \\
(41.4) \\
\end{array}$ & $1133(38)$ & $1847(62)$ & $\begin{array}{l}.896[.759, \\
1.058] \\
\end{array}$ & & $1.051[.845,1.306]$ & .657 \\
\hline Self-employed & $575(8)$ & $254(44.2)$ & $321(55.8)$ & $\begin{array}{l}1.156[.925 \\
1.443]\end{array}$ & & $.776[.586,1.026]$ & .075 \\
\hline
\end{tabular}


medRxiv preprint doi: https://doi.org/10.1101/2021.09.11.21263428; this version posted September 15, 2021. The copyright holder for this preprint (which was not certified by peer review) is the author/funder, who has granted medRxiv a license to display the preprint in perpetuity.

It is made available under a CC-BY-NC-ND 4.0 International license .

\begin{tabular}{|c|c|c|c|c|c|c|c|}
\hline Student & $\begin{array}{l}2831 \\
(39.4)\end{array}$ & $976(34.5)$ & $\begin{array}{l}1855 \\
(65.5)\end{array}$ & $\begin{array}{l}.768[.650, \\
.909]\end{array}$ & & $1.352[1.046,1.749]$ & .021 \\
\hline Housewife/retired/unemployed/other & $716(10)$ & $291(40.6)$ & $425(59.4)$ & Reference & & Reference & \\
\hline \multicolumn{8}{|l|}{ Monthly Income (PHP) } \\
\hline$\leq 10,000$ & $\begin{array}{l}2583 \\
(35.9)\end{array}$ & $\begin{array}{l}1004 \\
(38.9)\end{array}$ & $\begin{array}{l}1579 \\
(61.1)\end{array}$ & $\begin{array}{l}1.649 \\
{[1.417} \\
1.919]\end{array}$ & $<.001$ & $.596[.477, .745]$ & $<.001$ \\
\hline $10,000-20,000$ & $\begin{array}{l}954 \\
(13.3)\end{array}$ & $468(49.1)$ & $486(50.9)$ & $\begin{array}{l}2.497 \\
{[2.083,} \\
2.994]\end{array}$ & & $.587[.465, .741]$ & $<.001$ \\
\hline $20,000-100,000$ & $\begin{array}{l}2517 \\
(35)\end{array}$ & $907(36)$ & $1610(64)$ & $\begin{array}{l}1.461 \\
{[1.254} \\
1.702]\end{array}$ & & $.822[.679, .995]$ & .044 \\
\hline$\geq 100,000$ & $\begin{array}{l}1139 \\
(15.8)\end{array}$ & $317(27.8)$ & $822(72.2)$ & Reference & & Reference & \\
\hline \multicolumn{8}{|l|}{ Location } \\
\hline Urban & $\begin{array}{l}5676 \\
(78.9)\end{array}$ & $1985(35)$ & $3691(65)$ & & & Reference & \\
\hline Rural & $\begin{array}{l}1517 \\
(21.1)\end{array}$ & $711(46.9)$ & $806(53.1)$ & $\begin{array}{l}1.640 \\
{[1.463,} \\
1.840]\end{array}$ & $<.001$ & $.728[.634, .836]$ & $<.001$ \\
\hline \multicolumn{8}{|l|}{ Experience with COVID-19 } \\
\hline \multicolumn{8}{|l|}{ Ever tested positive for COVID-19 } \\
\hline Yes & $\begin{array}{l}211 \\
(2.9)\end{array}$ & $68(32.2)$ & $143(67.8)$ & & & & \\
\hline No & $\begin{array}{l}6982 \\
(97.1)\end{array}$ & $\begin{array}{l}2628 \\
(37.6)\end{array}$ & $\begin{array}{l}4354 \\
(62.4)\end{array}$ & $\begin{array}{l}.788[.588, \\
1.056]\end{array}$ & .110 & & \\
\hline \multicolumn{8}{|l|}{$\begin{array}{l}\text { Know anyone who has tested } \\
\text { positive for COVID-19 }\end{array}$} \\
\hline Yes & $\begin{array}{l}5234 \\
(72.8)\end{array}$ & $1780(34)$ & $3454(66)$ & & & $1.535[1.348,1.748]$ & $<.001$ \\
\hline No & $\begin{array}{l}1959 \\
(27.2)\end{array}$ & $916(46.8)$ & $\begin{array}{l}1043 \\
(53.2)\end{array}$ & $\begin{array}{l}.587[.528, \\
.652]\end{array}$ & $<.001$ & Reference & \\
\hline \multicolumn{8}{|l|}{ Health Characteristics } \\
\hline \multicolumn{8}{|l|}{ Have an existing chronic condition } \\
\hline Yes & $\begin{array}{l}1178 \\
(16.4)\end{array}$ & $396(33.6)$ & $782(66.4)$ & & & $1.149[.964,1.369]$ & .121 \\
\hline No & $\begin{array}{l}6015 \\
(83.6)\end{array}$ & $\begin{array}{l}2300 \\
(38.2)\end{array}$ & $\begin{array}{l}3715 \\
(61.8) \\
\end{array}$ & $\begin{array}{l}.818[.717, \\
.933]\end{array}$ & .003 & Reference & \\
\hline \multicolumn{8}{|l|}{ Perceived overall health } \\
\hline Very good & $\begin{array}{l}1997 \\
(27.8)\end{array}$ & $802(40.2)$ & $\begin{array}{l}1195 \\
(59.8)\end{array}$ & Reference & & Reference & \\
\hline Good & $\begin{array}{l}3934 \\
(54.7)\end{array}$ & $1376(35)$ & $2558(65)$ & $\begin{array}{l}.802[.717, \\
.896]\end{array}$ & $<.001$ & $1.173[1.024,1.343]$ & .021 \\
\hline Fair/Poor/Very poor & $\begin{array}{l}1262 \\
(17.5)\end{array}$ & $518(41)$ & $744(59)$ & $\begin{array}{l}1.037[.899, \\
1.197]\end{array}$ & & $.755[.632, .903]$ & .002 \\
\hline
\end{tabular}


medRxiv preprint doi: https://doi.org/10.1101/2021.09.11.21263428; this version posted September 15, 2021. The copyright holder for this preprint (which was not certified by peer review) is the author/funder, who has granted medRxiv a license to display the preprint in perpetuity.

\begin{tabular}{|c|c|c|c|c|c|c|c|}
\hline Health belief & & & & & & & \\
\hline \multicolumn{8}{|l|}{ Perceived susceptibility } \\
\hline \multicolumn{8}{|c|}{$\begin{array}{l}\text { Chance of getting COVID-19 in the } \\
\text { next few months is high }\end{array}$} \\
\hline Strongly agree/agree & $\begin{array}{l}2264 \\
(31.5)\end{array}$ & $\begin{array}{l}1595 \\
(70.5)\end{array}$ & $669(29.5)$ & $\begin{array}{l}1.665 \\
{[1.497} \\
1.853]\end{array}$ & $<.001$ & Reference & \\
\hline Disagree/strongly disagree & $\begin{array}{l}4929 \\
(68.5)\end{array}$ & $\begin{array}{l}2027 \\
(41.1)\end{array}$ & $\begin{array}{l}2902 \\
(58.9)\end{array}$ & & & $.728[.639, .830]$ & $<.001$ \\
\hline \multicolumn{8}{|l|}{$\begin{array}{l}\text { Worry about the likelihood of } \\
\text { getting COVID-19 }\end{array}$} \\
\hline Strongly agree/agree & $\begin{array}{l}6047 \\
(84.1)\end{array}$ & $\begin{array}{l}2105 \\
(34.8)\end{array}$ & $\begin{array}{l}3942 \\
(65.2)\end{array}$ & $\begin{array}{l}1.994 \\
{[1.756,} \\
2.265]\end{array}$ & $<.001$ & Reference & \\
\hline Disagree/strongly disagree & $\begin{array}{l}1146 \\
(15.9)\end{array}$ & $591(51.6)$ & $555(48.4)$ & & & $.696[.584, .830]$ & $<.001$ \\
\hline \multicolumn{8}{|l|}{ Perceived severity } \\
\hline \multicolumn{8}{|l|}{$\begin{array}{l}\text { COVID-19 is serious with life- } \\
\text { threatening complications }\end{array}$} \\
\hline Strongly agree/agree & $\begin{array}{l}6928 \\
(96.3)\end{array}$ & $\begin{array}{l}2523 \\
(36.4)\end{array}$ & $\begin{array}{l}4405 \\
(63.6)\end{array}$ & $\begin{array}{l}3.283 \\
{[2.538,} \\
4.248]\end{array}$ & $<.001$ & Reference & \\
\hline Disagree/strongly disagree & $\begin{array}{l}265 \\
(.04)\end{array}$ & $173(65.3)$ & $95(34.7)$ & & & $.580[.410, .820]$ & .002 \\
\hline \multicolumn{8}{|c|}{$\begin{array}{l}\text { I will be very sick if I get COVID- } \\
19\end{array}$} \\
\hline Strongly agree/agree & $\begin{array}{l}5394 \\
(75)\end{array}$ & $\begin{array}{l}1911 \\
(35.4)\end{array}$ & $\begin{array}{l}3483 \\
(64.6)\end{array}$ & $\begin{array}{l}1.411 \\
{[1.266} \\
1.573]\end{array}$ & $<.001$ & Reference & \\
\hline Disagree/strongly disagree & $\begin{array}{l}1799 \\
(25)\end{array}$ & 785 (43.6) & $\begin{array}{l}1014 \\
(56.4)\end{array}$ & & & $.824[.711, .954]$ & .010 \\
\hline \multicolumn{8}{|l|}{ I am afraid of getting COVID-19 } \\
\hline Strongly agree/agree & $\begin{array}{l}6700 \\
(93.1)\end{array}$ & $\begin{array}{l}2439 \\
(36.4)\end{array}$ & $\begin{array}{l}4261 \\
(63.6)\end{array}$ & $\begin{array}{l}1.902 \\
{[1.583,} \\
2.286]\end{array}$ & $<.001$ & Reference & \\
\hline Disagree/strongly disagree & $\begin{array}{l}493 \\
(.07)\end{array}$ & $257(52.1)$ & $236(47.9)$ & & & $.676[.513, .889]$ & .005 \\
\hline \multicolumn{8}{|l|}{ Perceived benefits } \\
\hline \multicolumn{8}{|l|}{$\begin{array}{l}\text { Vaccination will decrease my } \\
\text { chances of getting COVID-19 }\end{array}$} \\
\hline Strongly agree/agree & $\begin{array}{l}6339 \\
(88.1)\end{array}$ & $\begin{array}{l}2006 \\
(31.6)\end{array}$ & $\begin{array}{l}4333 \\
(68.4)\end{array}$ & $\begin{array}{l}9.088 \\
{[7.604,} \\
10.862]\end{array}$ & $<.001$ & Reference & \\
\hline Disagree/strongly disagree & $\begin{array}{l}854 \\
(11.9)\end{array}$ & $690(80.8)$ & $164(19.2)$ & & & $.291[.229, .370]$ & $<.001$ \\
\hline \multicolumn{8}{|c|}{$\begin{array}{l}\text { Vaccination will decrease my } \\
\text { worries about catching COVID-19 }\end{array}$} \\
\hline Strongly agree/agree & 6078 & 1833 & 4245 & 7.931 & $<.001$ & Reference & \\
\hline
\end{tabular}


medRxiv preprint doi: https://doi.org/10.1101/2021.09.11.21263428; this version posted September 15, 2021. The copyright holder for this preprint (which was not certified by peer review) is the author/funder, who has granted medRxiv a license to display the preprint in perpetuity.

It is made available under a CC-BY-NC-ND 4.0 International license .

\begin{tabular}{|c|c|c|c|c|c|c|c|}
\hline & $(84.5)$ & $(30.2)$ & $(69.8)$ & $\begin{array}{l}{[6.822,} \\
9.220]\end{array}$ & & & \\
\hline Disagree/strongly disagree & $\begin{array}{l}1115 \\
(15.5)\end{array}$ & $863(77.4)$ & $252(22.6)$ & & & $.265[.218, .323]$ & $<.001$ \\
\hline \multicolumn{8}{|l|}{ Perceived barriers } \\
\hline \multicolumn{8}{|c|}{$\begin{array}{l}\text { Worry about the possible side- } \\
\text { effects of the COVID-19 vaccine }\end{array}$} \\
\hline Strongly agree/agree & $\begin{array}{l}6447 \\
(89.6)\end{array}$ & $\begin{array}{l}2647 \\
(41.1)\end{array}$ & $\begin{array}{l}3800 \\
(58.9)\end{array}$ & $\begin{array}{l}.101[.075, \\
.135]\end{array}$ & $<.001$ & Reference & \\
\hline Disagree/strongly disagree & $\begin{array}{l}746 \\
(10.4)\end{array}$ & $49(6.6)$ & $697(93.4)$ & & & $3.053[2.107,4.424]$ & $<.001$ \\
\hline \multicolumn{8}{|c|}{$\begin{array}{l}\text { I worry about the effectiveness of } \\
\text { the COVID-19 vaccine }\end{array}$} \\
\hline Strongly agree/agree & $\begin{array}{l}6263 \\
(87.1)\end{array}$ & $\begin{array}{l}2581 \\
(41.2)\end{array}$ & $\begin{array}{l}3682 \\
(58.8)\end{array}$ & $\begin{array}{l}.201[.165, \\
.246]\end{array}$ & $<.001$ & Reference & \\
\hline Disagree/strongly disagree & $\begin{array}{l}930 \\
(12.9)\end{array}$ & $115(12.4)$ & $815(87.6)$ & & & $1.358[1.022,1.805]$ & .035 \\
\hline \multicolumn{8}{|l|}{$\begin{array}{l}\text { I worry about the safety of the } \\
\text { COVID-19 vaccine }\end{array}$} \\
\hline Strongly agree/agree & $\begin{array}{l}6389 \\
(88.8)\end{array}$ & $\begin{array}{l}2626 \\
(41.1)\end{array}$ & $\begin{array}{l}3763 \\
(58.9)\end{array}$ & $\begin{array}{l}.137[.106, \\
.176]\end{array}$ & $<.001$ & Reference & \\
\hline Disagree/strongly disagree & $\begin{array}{l}804 \\
(11.2)\end{array}$ & $70(8.7)$ & $734(91.3)$ & & & $1.593[1.115,2.277]$ & .011 \\
\hline \multicolumn{8}{|c|}{$\begin{array}{l}\text { I worry about the high cost of the } \\
\text { COVID-19 vaccine }\end{array}$} \\
\hline Strongly agree/agree & $\begin{array}{l}5608 \\
(78)\end{array}$ & $2301(41)$ & 3307 (59) & $\begin{array}{l}.477[.421, \\
.541]\end{array}$ & $<.001$ & Reference & \\
\hline Disagree/strongly disagree & $\begin{array}{l}1585 \\
(22)\end{array}$ & $395(24.9)$ & $\begin{array}{l}1190 \\
(75.1)\end{array}$ & & & $1.128[.958,1.327]$ & .147 \\
\hline \multicolumn{8}{|l|}{$\begin{array}{l}\text { I worry about fake COVID-19 } \\
\text { vaccines }\end{array}$} \\
\hline Strongly agree/agree & $\begin{array}{l}7006 \\
(97.4)\end{array}$ & $\begin{array}{l}2646 \\
(37.8)\end{array}$ & $\begin{array}{l}4360 \\
(62.2)\end{array}$ & $\begin{array}{l}.601[.433, \\
.834]\end{array}$ & .002 & Reference & \\
\hline Disagree/strongly disagree & $\begin{array}{l}187 \\
(.03)\end{array}$ & $50(26.7)$ & $197(73.3)$ & & & $.599[.399, .900]$ & .014 \\
\hline \multicolumn{8}{|c|}{$\begin{array}{l}\text { I worry that the COVID-19 vaccines } \\
\text { will make me sick }\end{array}$} \\
\hline Strongly agree/agree & $\begin{array}{l}4918 \\
(68.4)\end{array}$ & $\begin{array}{l}2404 \\
(48.9)\end{array}$ & $\begin{array}{l}2514 \\
(51.1)\end{array}$ & $\begin{array}{l}.154[.135, \\
.176]\end{array}$ & $<.001$ & Reference & \\
\hline Disagree/strongly disagree & $\begin{array}{l}2275 \\
(31.6)\end{array}$ & $292(12.8)$ & $\begin{array}{l}1983 \\
(87.2)\end{array}$ & & & $2.913[2.467,3.440]$ & $<.001$ \\
\hline \multicolumn{8}{|c|}{$\begin{array}{l}\text { I worry the COVID-19 vaccines will } \\
\text { not be effective against new virus } \\
\text { variants }\end{array}$} \\
\hline Strongly agree/agree & $\begin{array}{l}5757 \\
(80)\end{array}$ & $\begin{array}{l}2506 \\
(43.5)\end{array}$ & $\begin{array}{l}3251 \\
(56.5)\end{array}$ & $\begin{array}{l}.198[.168, \\
.232]\end{array}$ & $<.001$ & Reference & \\
\hline Disagree/strongly disagree & $\begin{array}{l}1436 \\
(20)\end{array}$ & $190(13.2)$ & $\begin{array}{l}1246 \\
(86.8)\end{array}$ & & & $1.831[1.502,2.232]$ & $<.001$ \\
\hline
\end{tabular}


medRxiv preprint doi: https://doi.org/10.1101/2021.09.11.21263428; this version posted September 15, 2021. The copyright holder for this preprint (which was not certified by peer review) is the author/funder, who has granted medRxiv a license to display the preprint in perpetuity.

It is made available under a CC-BY-NC-ND 4.0 International license .

\begin{tabular}{|c|l|l|l|l|l|l|}
\hline Cues to action & & & & & \\
\hline $\begin{array}{l}\text { I will only receive the COVID-19 } \\
\text { vaccines after many others receive it }\end{array}$ & & & & & \\
\hline Strongly agree/agree & $\begin{array}{l}5237 \\
(72.8)\end{array}$ & $\begin{array}{l}2278 \\
(43.5)\end{array}$ & $\begin{array}{l}2959 \\
(56.5)\end{array}$ & $\begin{array}{l}.353[.313, \\
.398]\end{array}$ & $<.001$ & Reference \\
\hline $\begin{array}{c}\text { Disagree/strongly disagree } \\
1956\end{array}$ & $418(21.4)$ & $\begin{array}{l}1538 \\
(78.6)\end{array}$ & & & $1.894[1.597,2.247]$ & $<.001$ \\
\hline $\begin{array}{c}\text { I will only receive the COVID-19 } \\
\text { vaccines after politicians receive it }\end{array}$ & $\begin{array}{l}4908 \\
(68.2)\end{array}$ & $\begin{array}{l}2124 \\
(43.3)\end{array}$ & $\begin{array}{l}2784 \\
(56.7)\end{array}$ & $\begin{array}{l}.438[.392, \\
.489]\end{array}$ & $<.001$ & Reference \\
\hline Strongly agree/agree & $\begin{array}{l}2285 \\
(31.8)\end{array}$ & $572(25)$ & $1713(75)$ & & $1.411[1.214,1.640]$ & $<.001$ \\
\hline
\end{tabular}


medRxiv preprint doi: https://doi.org/10.1101/2021.09.11.21263428; this version posted September 15, 2021. The copyright holder for this preprint (which was not certified by peer review) is the author/funder, who has granted medRxiv a license to display the preprint in perpetuity.

It is made available under a CC-BY-NC-ND 4.0 International license . 
medRxiv preprint doi: https://doi.org/10.1101/2021.09.11.21263428; this version posted September 15, 2021. The copyright holder for this preprint (which was not certified by peer review) is the author/funder, who has granted medRxiv a license to display the preprint in perpetuity.

It is made available under a CC-BY-NC-ND 4.0 International license .

Table 3: Willingness to Pay for a COVID-19 Vaccine

\begin{tabular}{|c|c|}
\hline $\begin{array}{c}\text { Maximum Amount Willing to Pay } \\
\text { (PHP: Philippine Peso) }\end{array}$ & \% of Respondents \\
\hline PHP 500 & $18.8 \%$ \\
\hline PHP 1,000 & $21 \%$ \\
\hline PHP 1,500 & $12 \%$ \\
\hline PHP 2,000 & $16 \%$ \\
\hline PHP 2,500 & $6.8 \%$ \\
\hline PHP 3,000 & $8.8 \%$ \\
\hline PHP 3,500 & $1.9 \%$ \\
\hline PHP 4,000 & $14.7 \%$ \\
\hline
\end{tabular}


medRxiv preprint doi: https://doi.org/10.1101/2021.09.11.21263428; this version posted September 15, 2021. The copyright holder for this preprint (which was not certified by peer review) is the author/funder, who has granted medRxiv a license to display the preprint in perpetuity.

It is made available under a CC-BY-NC-ND 4.0 International license .

Table 4: Multinomial Logistic Regression of Factors Associated with Marginal Willingnessto-Pay (WTP) for a COVID-19 vaccine $(\mathrm{N}=7,193)$

\begin{tabular}{|c|c|c|c|c|c|c|c|c|}
\hline & \multirow{2}{*}{\multicolumn{3}{|c|}{$\begin{array}{c}\text { Univariable analysis } \\
\text { Marginal WTP }(\square=\text { PHP) }\end{array}$}} & \multirow[b]{3}{*}{$\begin{array}{c}p- \\
\text { valu } \\
\text { e }\end{array}$} & \multicolumn{4}{|c|}{ Multinomial logistic regression } \\
\hline & & & & & \multirow[b]{2}{*}{$\begin{array}{c}\square \mathbf{1 5 0 0 / 2 0} \\
\mathbf{0 0} \\
/ 2500 \\
\text { OR [95\% } \\
\text { CI }]\end{array}$} & \multirow[b]{2}{*}{$\begin{array}{c}p- \\
\text { valu } \\
\text { e }\end{array}$} & \multirow[b]{2}{*}{$\begin{array}{c}\square 3000 / 3 \\
500 \\
/ 4000 \\
\text { OR } \\
{[95 \%} \\
\text { CI }]\end{array}$} & \multirow[b]{2}{*}{$\begin{array}{c}p- \\
\text { valu } \\
\text { e }\end{array}$} \\
\hline & $\begin{array}{c}\mathbf{5 0 0} / \mathbf{1 0 0} \\
\mathbf{0} \\
(\mathrm{US} \\
\mathbf{\$ 1 0 . 1 8} / \\
\mathbf{2 0 . 3 6}) \\
\mathbf{n}=\mathbf{2 8 6 2} \\
(\%)\end{array}$ & $\begin{array}{c}\square \mathbf{1 5 0 0 / 2 0 0} \\
\mathbf{0} \\
/ 2500 \\
(\mathbf{U S} \\
\mathbf{\$ 3 0 . 5 5 / 4 0 . 7} \\
\mathbf{3} \\
/ \mathbf{5 0 . 9 1}) \\
\mathbf{n}=\mathbf{2 5 0 5} \\
(\%)\end{array}$ & $\begin{array}{c}3000 / 35 \\
00 \\
/ 4000 \\
\text { (US \$ } \\
61.09 / 71.2 \\
8 \\
/ 81.46) \\
\text { n }=1826 \\
(\%)\end{array}$ & & & & & \\
\hline \multicolumn{9}{|l|}{ Demographics } \\
\hline \multicolumn{9}{|l|}{ Age group (years) } \\
\hline $18-30$ & $\begin{array}{c}1349 \\
(35.8)\end{array}$ & $1480(39.3)$ & $941(25)$ & $<.001$ & $\begin{array}{l}1.895 \\
{[1.401} \\
2.563]\end{array}$ & $<.001$ & $\begin{array}{l}2.344 \\
{[1.616} \\
3.400]\end{array}$ & $<.001$ \\
\hline $31-40$ & $352(43.2)$ & $233(28.6)$ & $230(28.2)$ & & $\begin{array}{l}1.960 \\
{[1.401} \\
2.611]\end{array}$ & $<.001$ & $\begin{array}{l}2.895 \\
{[2.045} \\
4.100]\end{array}$ & $<.001$ \\
\hline $41-50$ & $363(42.2)$ & $266(30.9)$ & $232(26.9)$ & & $\begin{array}{l}1.640 \\
{[1.256} \\
2.143]\end{array}$ & $<.001$ & $\begin{array}{l}1.812 \\
{[1.309} \\
2.507]\end{array}$ & $<.001$ \\
\hline $51-60$ & $418(46.4)$ & $269(29.9)$ & $213(23.7)$ & & $\begin{array}{l}1.261[.982, \\
1.621]\end{array}$ & .070 & $\begin{array}{l}1.229 \\
{[.902} \\
1.675]\end{array}$ & .192 \\
\hline $61-89$ & $380(44.9)$ & $257(30.3)$ & $210(24.8)$ & & Reference & & Reference & \\
\hline \multicolumn{9}{|l|}{ Gender } \\
\hline Female & $\begin{array}{c}1912 \\
(39.9)\end{array}$ & $1682(35.1)$ & $1195(25)$ & .391 & & & & \\
\hline Male & $950(39.5)$ & $823(34.2)$ & $631(26.2)$ & & & & & \\
\hline \multicolumn{9}{|l|}{ Marital Status } \\
\hline Single & $\begin{array}{c}1727 \\
(36.6)\end{array}$ & $1768(37.4)$ & $1229(26)$ & $<.001$ & $\begin{array}{l}1.200 \\
{[1.003} \\
1.436]\end{array}$ & .046 & $\begin{array}{l}1.328 \\
{[1.069} \\
1.649]\end{array}$ & .010 \\
\hline Married & $1135(46)$ & 737 (29.9) & $597(24.2)$ & & Reference & & Reference & \\
\hline \multicolumn{9}{|l|}{ Highest Education Level } \\
\hline Elementary school or below & 1 & & & \multicolumn{5}{|c|}{$n$ too small to calculate } \\
\hline Junior high school & $19(41.3)$ & $14(30.4)$ & $13(28.3)$ & & $\begin{array}{l}.838[.396, \\
1.771]\end{array}$ & .643 & $\begin{array}{l}1.958 \\
{[.899} \\
4.264]\end{array}$ & .091 \\
\hline Senior high school & $328(29.8)$ & $474(43)$ & $300(27.2)$ & $<.001$ & $\begin{array}{l}1.153[.956, \\
1.390]\end{array}$ & .136 & $\begin{array}{l}1.203 \\
{[.958} \\
1.510]\end{array}$ & .111 \\
\hline College/university of above & 2514 & $2017(33.4)$ & $1513(25)$ & & Reference & & Reference & \\
\hline
\end{tabular}


medRxiv preprint doi: https://doi.org/10.1101/2021.09.11.21263428; this version posted September 15, 2021. The copyright holder for this preprint (which was not certified by peer review) is the author/funder, who has granted medRxiv a license to display the preprint in perpetuity.

It is made available under a CC-BY-NC-ND 4.0 International license .

\begin{tabular}{|c|c|c|c|c|c|c|c|c|}
\hline & (41.6) & & & & & & & \\
\hline \multicolumn{9}{|l|}{ Occupation } \\
\hline Blue collar worker & $69(75.8)$ & $13(14.3)$ & $9(9.9)$ & $<.001$ & $\begin{array}{l}.238[.124, \\
.456]\end{array}$ & $<.001$ & $\begin{array}{l}.304[.135, \\
.681]\end{array}$ & .004 \\
\hline $\begin{array}{l}\text { Professional/white collar } \\
\text { worker }\end{array}$ & $\begin{array}{c}1382 \\
(46.4)\end{array}$ & $845(28.4)$ & $753(25.3)$ & & $\begin{array}{l}.681[.539, \\
.860]\end{array}$ & .001 & $\begin{array}{l}.866[.644, \\
1.163]\end{array}$ & .339 \\
\hline Self-employed & $226(39.3)$ & $204(35.5)$ & $145(25.2)$ & & $\begin{array}{l}1.052[.795, \\
1.393]\end{array}$ & .722 & $\begin{array}{l}1.127 \\
{[.785,} \\
1.616]\end{array}$ & .517 \\
\hline Student & $585(30.3)$ & $1213(42.8)$ & $760(26.8)$ & & $\begin{array}{l}1.614 \\
{[1.206,} \\
2.159]\end{array}$ & .001 & $\begin{array}{l}1.725 \\
{[1.190} \\
2.501]\end{array}$ & .004 \\
\hline $\begin{array}{l}\text { Housewife/retired/unemployed/ot } \\
\text { her }\end{array}$ & $327(45.7)$ & $230(32.1)$ & $159(22.2)$ & & Reference & & Reference & \\
\hline \multicolumn{9}{|l|}{ Monthly Income (PHP) } \\
\hline$\leq 10,000$ & $986(38.2)$ & $995(38.5)$ & $602(23.3)$ & & $\begin{array}{l}.378[.298, \\
.480]\end{array}$ & $<.001$ & $\begin{array}{l}.252[.191, \\
.333]\end{array}$ & $<.001$ \\
\hline $10,000-20,000$ & $554(58.1)$ & $272(28.5)$ & $128(13.4)$ & $<.001$ & $\begin{array}{l}.389[.305, \\
.497]\end{array}$ & $<.001$ & $\begin{array}{l}.211[.156, \\
.286]\end{array}$ & $<.001$ \\
\hline $20,000-100,000$ & $\begin{array}{c}1047 \\
(41.6)\end{array}$ & $849(33.7)$ & $621(24.7)$ & & $\begin{array}{l}.614[.503, \\
.749]\end{array}$ & $<.001$ & $\begin{array}{l}.452[.362, \\
.563]\end{array}$ & $<.001$ \\
\hline$\geq 100,000$ & $275(24.1)$ & $389(34.2)$ & $475(41.7)$ & & Reference & & Reference & \\
\hline \multicolumn{9}{|l|}{ Location } \\
\hline Urban & $\begin{array}{l}2053 \\
(36.2)\end{array}$ & $2068(36.4)$ & $1555(27.4)$ & & Reference & & Reference & \\
\hline Rural & $809(53.3)$ & $437(28.8)$ & $271(17.9)$ & $<.001$ & $\begin{array}{l}.584[.505, \\
.674]\end{array}$ & $<.001$ & $\begin{array}{l}.552[.460, \\
.662]\end{array}$ & $<.001$ \\
\hline \multicolumn{9}{|l|}{ Experience with COVID-19 } \\
\hline \multicolumn{9}{|l|}{$\begin{array}{l}\text { Ever tested positive for COVID- } \\
19\end{array}$} \\
\hline Yes & $80(37.9)$ & $66(31.3)$ & $65(30.8)$ & .176 & & & & \\
\hline No & $\begin{array}{l}2782 \\
(39.8)\end{array}$ & $2439(34.9)$ & $1761(25.2)$ & & & & & \\
\hline \multicolumn{9}{|l|}{$\begin{array}{l}\text { Know anyone who has tested } \\
\text { positive for COVID-19 }\end{array}$} \\
\hline Yes & $\begin{array}{l}1932 \\
(36.9)\end{array}$ & $1868(35.7)$ & $1434(27.4)$ & $<.001$ & $\begin{array}{l}1.336 \\
{[1.169,} \\
1.527]\end{array}$ & $<.001$ & $\begin{array}{l}1.419 \\
{[1.201,} \\
1.678]\end{array}$ & $<.001$ \\
\hline No & $930(47.5)$ & $637(32.5)$ & $392(20)$ & & Reference & & Reference & \\
\hline \multicolumn{9}{|l|}{ Health Characteristics } \\
\hline \multicolumn{9}{|l|}{$\begin{array}{l}\text { Have an existing chronic } \\
\text { condition }\end{array}$} \\
\hline Yes & $438(37.2)$ & 387 (32.9) & $353(30)$ & .001 & $\begin{array}{l}1.176[.981, \\
1.410]\end{array}$ & .080 & $\begin{array}{l}1.430 \\
{[1.152,} \\
1.775]\end{array}$ & .001 \\
\hline No & 2424 & $2118(35.2)$ & $1473(24.5)$ & & Reference & & Reference & \\
\hline
\end{tabular}


medRxiv preprint doi: https://doi.org/10.1101/2021.09.11.21263428; this version posted September 15, 2021. The copyright holder for this preprint (which was not certified by peer review) is the author/funder, who has granted medRxiv a license to display the preprint in perpetuity.

It is made available under a CC-BY-NC-ND 4.0 International license .

\begin{tabular}{|c|c|c|c|c|c|c|c|c|}
\hline & $(40.3)$ & & & & & & & \\
\hline \multicolumn{9}{|l|}{ Perceived overall health } \\
\hline Very good & $852(42.7)$ & $641(32.1)$ & $504(25.2)$ & & Reference & & Reference & \\
\hline Good & $\begin{array}{c}1559 \\
(39.6)\end{array}$ & $1385(35.2)$ & $990(25.2)$ & & $\begin{array}{l}1.160 \\
{[1.010,} \\
1.332]\end{array}$ & .035 & $\begin{array}{l}1.052 \\
{[.891} \\
1.243]\end{array}$ & .549 \\
\hline Fair/Poor/Very poor & $451(35.7)$ & $479(38)$ & $332(26.3)$ & .020 & $\begin{array}{l}1.287 \\
{[1.071} \\
1.547]\end{array}$ & .007 & $\begin{array}{l}1.090 \\
{[.872,} \\
1.364]\end{array}$ & .450 \\
\hline \multicolumn{9}{|l|}{ Health belief } \\
\hline \multicolumn{9}{|l|}{ Perceived susceptibility } \\
\hline \multicolumn{9}{|l|}{$\begin{array}{l}\text { Chance of getting COVID-19 in } \\
\text { the next few months is high }\end{array}$} \\
\hline Strongly agree/agree & $838(37)$ & $790(34.9)$ & $636(28.1)$ & $<.001$ & Reference & & Reference & \\
\hline Disagree/strongly disagree & $\begin{array}{c}2024 \\
(41.1) \\
\end{array}$ & $1715(34.8)$ & $1190(24.1)$ & & $\begin{array}{l}.989[.868 \\
1.128]\end{array}$ & .872 & $\begin{array}{l}.916[.783, \\
1.071]\end{array}$ & .270 \\
\hline \multicolumn{9}{|l|}{$\begin{array}{l}\text { Worry about the likelihood of } \\
\text { getting COVID-19 }\end{array}$} \\
\hline Strongly agree/agree & $\begin{array}{c}2272 \\
(37.6)\end{array}$ & $2175(36)$ & $1600(26.5)$ & $<.001$ & Reference & & Reference & \\
\hline Disagree/strongly disagree & $590(51.5)$ & $330(28.8)$ & $226(19.7)$ & & $\begin{array}{l}.763[.638, \\
.912]\end{array}$ & .003 & $\begin{array}{l}.690[.551, \\
.866]\end{array}$ & .001 \\
\hline \multicolumn{9}{|l|}{ Perceived severity } \\
\hline \multicolumn{9}{|l|}{$\begin{array}{l}\text { COVID-19 is serious with life- } \\
\text { threatening complications }\end{array}$} \\
\hline Strongly agree/agree & $2699(39)$ & $2441(35.2)$ & $1788(25.8)$ & $<.001$ & Reference & & Reference & \\
\hline Disagree/strongly disagree & $163(61.5)$ & $64(24.2)$ & $38(14.3)$ & & $\begin{array}{l}.681[.484, \\
.960]\end{array}$ & .028 & $\begin{array}{l}.562[.654, \\
.891]\end{array}$ & .014 \\
\hline \multicolumn{9}{|l|}{$\begin{array}{l}\text { I will be very sick if I get } \\
\text { COVID-19 }\end{array}$} \\
\hline Strongly agree/agree & $2048(38)$ & $1931(35.8)$ & $1415(26.2)$ & $<.001$ & Reference & & Reference & \\
\hline Disagree/strongly disagree & $814(45.2)$ & $574(31.9)$ & $411(22.8)$ & & $\begin{array}{l}.883[.762 \\
1.023]\end{array}$ & .097 & $\begin{array}{l}.784[.654, \\
.940]\end{array}$ & .009 \\
\hline \multicolumn{9}{|l|}{ I am afraid of getting COVID-19 } \\
\hline Strongly agree/agree & $\begin{array}{c}2619 \\
(39.1)\end{array}$ & $2354(35.1)$ & $1727(25.8)$ & $<.001$ & Reference & & Reference & \\
\hline Disagree/strongly disagree & $243(49.3)$ & $151(30.6)$ & $99(20.1)$ & & $\begin{array}{l}.989[.759 \\
1.290]\end{array}$ & .938 & $\begin{array}{l}.794[.562 \\
1.122]\end{array}$ & .192 \\
\hline \multicolumn{9}{|l|}{ Perceived benefits } \\
\hline \multicolumn{9}{|l|}{$\begin{array}{l}\text { Vaccination will decrease my } \\
\text { chances of getting COVID- } 19\end{array}$} \\
\hline Strongly agree/agree & $\begin{array}{c}2341 \\
(36.9)\end{array}$ & $2289(36.1)$ & 1709 (27) & $<.001$ & Reference & & Reference & \\
\hline
\end{tabular}


medRxiv preprint doi: https://doi.org/10.1101/2021.09.11.21263428; this version posted September 15, 2021. The copyright holder for this preprint (which was not certified by peer review) is the author/funder, who has granted medRxiv a license to display the preprint in perpetuity.

It is made available under a CC-BY-NC-ND 4.0 International license .

\begin{tabular}{|c|c|c|c|c|c|c|c|c|}
\hline Disagree/strongly disagree & $521(61)$ & $216(25.3)$ & $117(13.7)$ & & $\begin{array}{l}.666[.526, \\
.842]\end{array}$ & .001 & $\begin{array}{l}.532[.391, \\
.724]\end{array}$ & $<.001$ \\
\hline \multicolumn{9}{|l|}{$\begin{array}{l}\text { Vaccination will decrease my } \\
\text { worries about catching COVID- } \\
19\end{array}$} \\
\hline Strongly agree/agree & $2248(37)$ & $2180(35.9)$ & $1650(27.1)$ & $<.001$ & Reference & & Reference & \\
\hline Disagree/strongly disagree & $614(55.1)$ & $325(29.1)$ & $176(15.8)$ & & & & $\begin{array}{l}.688[.529, \\
.895]\end{array}$ & .005 \\
\hline \multicolumn{9}{|l|}{ Perceived barriers } \\
\hline \multicolumn{9}{|l|}{$\begin{array}{l}\text { Worry about the possible side- } \\
\text { effects of the COVID-19 vaccine }\end{array}$} \\
\hline Strongly agree/agree & $\begin{array}{l}2701 \\
(41.9)\end{array}$ & $2212(34.3)$ & $1534(23.8)$ & $<.001$ & Reference & & Reference & \\
\hline Disagree/strongly disagree & $161(21.6)$ & $293(39.3)$ & $292(39.1)$ & & $\begin{array}{l}1.421 \\
{[1.103} \\
1.831]\end{array}$ & .007 & $\begin{array}{l}1.262 \\
{[.945} \\
1.684]\end{array}$ & .114 \\
\hline \multicolumn{9}{|l|}{$\begin{array}{l}\text { I worry about the effectiveness of } \\
\text { the COVID-19 vaccine }\end{array}$} \\
\hline Strongly agree/agree & $\begin{array}{l}2590 \\
(41.4)\end{array}$ & $2184(34.9)$ & $1489(23.8)$ & $<.001$ & Reference & & Reference & \\
\hline Disagree/strongly disagree & $272(29.2)$ & $321(34.5)$ & $337(36.2)$ & & $\begin{array}{l}.917[.712, \\
1.182]\end{array}$ & .505 & $\begin{array}{l}.756[.564, \\
1.015]\end{array}$ & .063 \\
\hline \multicolumn{9}{|l|}{$\begin{array}{l}\text { I worry about the safety of the } \\
\text { COVID- } 19 \text { vaccine }\end{array}$} \\
\hline Strongly agree/agree & $\begin{array}{c}2637 \\
(41.3)\end{array}$ & $2240(35.1)$ & $1512(23.7)$ & $<.001$ & Reference & & Reference & \\
\hline Disagree/strongly disagree & $225(28)$ & $265(33)$ & $314(39.1)$ & & $\begin{array}{l}.768[.578, \\
1.022]\end{array}$ & .070 & $\begin{array}{l}.895[.645, \\
1.243]\end{array}$ & .508 \\
\hline \multicolumn{9}{|l|}{$\begin{array}{l}\text { I worry about the high cost of the } \\
\text { COVID-19 vaccine }\end{array}$} \\
\hline Strongly agree/agree & $\begin{array}{l}2616 \\
(46.6)\end{array}$ & $1991(35.5)$ & $1001(17.8)$ & $<.001$ & Reference & & Reference & \\
\hline Disagree/strongly disagree & $246(15.5)$ & $514(32.4)$ & $825(52.1)$ & & $\begin{array}{l}2.534 \\
{[2.107} \\
3.048]\end{array}$ & $<.001$ & $\begin{array}{l}7.321 \\
{[6.065} \\
8.836]\end{array}$ & $<.001$ \\
\hline \multicolumn{9}{|l|}{$\begin{array}{l}\text { I worry about fake COVID-19 } \\
\text { vaccines }\end{array}$} \\
\hline Strongly agree/agree & $\begin{array}{l}2809 \\
(40.1)\end{array}$ & $2452(35)$ & $1745(24.9)$ & $<.001$ & Reference & & Reference & \\
\hline Disagree/strongly disagree & $53(28.3)$ & $53(28.3)$ & $81(43.3)$ & & $\begin{array}{l}.723[.471, \\
1.108]\end{array}$ & .136 & $\begin{array}{l}1.093 \\
{[.707} \\
1.690]\end{array}$ & .688 \\
\hline $\begin{array}{l}\text { I worry that the COVID-19 } \\
\text { vaccines will make me sick }\end{array}$ & & & & & & & & \\
\hline
\end{tabular}


medRxiv preprint doi: https://doi.org/10.1101/2021.09.11.21263428; this version posted September 15, 2021. The copyright holder for this preprint (which was not certified by peer review) is the author/funder, who has granted medRxiv a license to display the preprint in perpetuity.

It is made available under a CC-BY-NC-ND 4.0 International license .

\begin{tabular}{|c|c|c|c|c|c|c|c|c|}
\hline Strongly agree/agree & $\begin{array}{c}2254 \\
(45.8)\end{array}$ & $1640(33.3)$ & $1024(20.8)$ & $<.001$ & Reference & & Reference & \\
\hline Disagree/strongly disagree & $608(26.7)$ & $865(38)$ & $802(35.3)$ & & $\begin{array}{l}1.407 \\
{[1.200,} \\
1.650]\end{array}$ & $<.001$ & $\begin{array}{l}1.431 \\
{[1.188} \\
1.725]\end{array}$ & $<.001$ \\
\hline \multicolumn{9}{|l|}{$\begin{array}{l}\text { I worry the COVID-19 vaccines } \\
\text { will not be effective against new } \\
\text { virus variants }\end{array}$} \\
\hline Strongly agree/agree & $\begin{array}{c}2463 \\
(42.8)\end{array}$ & $1984(34.5)$ & $1310(22.8)$ & $<.001$ & Reference & & Reference & \\
\hline Disagree/strongly disagree & $399(27.8)$ & $521(36.3)$ & $516(35.9)$ & & $\begin{array}{l}1.109[.927, \\
1.327]\end{array}$ & .259 & $\begin{array}{l}1.245 \\
{[1.016} \\
1.525]\end{array}$ & .035 \\
\hline \multicolumn{9}{|l|}{ Cues to action } \\
\hline \multicolumn{9}{|c|}{$\begin{array}{l}\text { I will only receive the COVID- } 19 \\
\text { vaccines after many others } \\
\text { receive it }\end{array}$} \\
\hline Strongly agree/agree & $\begin{array}{c}2235 \\
(42.7) \\
\end{array}$ & $1833(35)$ & $1169(22.3)$ & $<.001$ & Reference & & Reference & \\
\hline Disagree/strongly disagree & $627(32.1)$ & $672(34.4)$ & $657(33.6)$ & & $\begin{array}{l}1.068[.909, \\
1.254]\end{array}$ & .425 & $\begin{array}{l}1.103 \\
{[.913} \\
1.333]\end{array}$ & .309 \\
\hline \multicolumn{9}{|c|}{$\begin{array}{l}\text { I will only receive the COVID- } 19 \\
\text { vaccines after politicians receive } \\
\text { it }\end{array}$} \\
\hline Strongly agree/agree & $\begin{array}{l}2142 \\
(43.6)\end{array}$ & $1725(35.1)$ & $1041(21.2)$ & $<.001$ & Reference & & Reference & \\
\hline Disagree/strongly disagree & $720(31.5)$ & $780(34.1)$ & $785(34.4)$ & & $\begin{array}{l}1.111[.957, \\
1.289]\end{array}$ & .167 & $\begin{array}{l}1.495 \\
{[1.256} \\
1.780]\end{array}$ & $<.001$ \\
\hline
\end{tabular}

